\title{
An illustrated guide for characters and terminology used in descriptions of Phlebotominae (Diptera, Psychodidae)
}

\author{
Eunice A. B. Galati ${ }^{1}$, Fredy Galvis-Ovallos ${ }^{1}$, Phillip Lawyer ${ }^{2,3}$, Nicole Léger ${ }^{4}$, and Jérôme Depaquit ${ }^{4, *}$ \\ 1 Departamento de Epidemiologia, Faculdade de Saúde Pública, Universidade de São Paulo, Av. Dr. Arnaldo 715, 01246-904 São Paulo, \\ Brazil \\ 2 Laboratory of Parasitic Diseases, National Institute of Allergy and Infectious Diseases, National Institutes of Health, \\ Bethesda, MD 20892, USA \\ 3 Monte L. Bean Life Science Museum, Brigham Young University, Provo, UT 84602, USA \\ 4 Université de Reims Champagne-Ardenne, ANSES, SFR Cap Santé, EA4688-USC “Transmission vectorielle et épidémiosurveillance \\ de maladies parasitaires (VECPAR)", 51 rue Cognacq-Jay, 51096 Reims Cedex, France
}

Received 21 February 2017, Accepted 23 June 2017, Published online 21 July 2017

\begin{abstract}
Phlebotomine (Diptera, Psychodidae, Phlebotominae) taxonomy has been studied extensively, primarily due to the role of these flies as vectors of various parasites, including species of Leishmania, Bartonella and arboviruses that cause diseases in humans and other vertebrates. We present some topics discussed at a round-table on phlebotomine taxonomy held at the Ninth International Symposium on Phlebotomine Sandflies (ISOPS IX) in Reims, France, in June 2016. To date, approximately one thousand phlebotomine species have been described worldwide, although in varying languages and mostly without standardization of characters and terminology. In the interest of standardization, we list the characters that should minimally be considered in the description of new phlebotomine taxa as well as annotated illustrations of several characters. For these characters, multiple illustrations are provided to show some of the variations. The preferred terms for all pertinent characters are listed as well as their synonyms in English, Portuguese, and French. Finally, we offer an updated list of abbreviations to be used for generic and subgeneric names.
\end{abstract}

Key words: Phlebotominae, Taxonomy, Morphology, Species description.

Résumé - Guide illustré des caractères et de la terminologie utilisés dans les descriptions de Phlebotominae (Diptera, Psychodidae). La taxonomie des phlébotomes (Diptera, Psychodidae, Phlebotominae) a été largement étudiée, principalement en raison du rôle de ces diptères comme vecteurs de divers parasites, y compris des espèces de Leishmania, Bartonella et des arbovirus qui causent des maladies chez l'homme et d'autres vertébrés. Nous présentons certains thèmes abordés lors d'une table ronde sur la taxonomie des phlébotomes tenue lors du $9^{\text {ème }}$ Symposium international sur les phlébotomes (ISOPS IX) à Reims, France, en juin 2016. À ce jour, environ mille espèces de phlébotomes ont été décrites dans le monde entier, bien que dans des langues variées et surtout sans standardisation des caractères et de la terminologie. Dans l'intérêt de la normalisation, nous énumérons les caractères qui devraient être considérés lors de la description de nouveaux taxons de phlébotomes et fournissons des illustrations légendées de nombre d'entre eux. Pour ces caractères, plusieurs illustrations sont fournies pour montrer une partie de la variabilité. Les termes préférés pour tous les caractères pertinents sont répertoriés ainsi que leurs synonymes en anglais, portugais et français. Enfin, nous proposons une liste actualisée des abréviations à utiliser pour les genres et sous-genres.

\section{Introduction}

Phlebotomine (Diptera, Psychodidae, Phlebotominae) taxonomy has been studied extensively, primarily due to the role of these flies as vectors of various agents, including species of Leishmania, Bartonella and arboviruses that cause infections in humans and other vertebrates. To date, approximately one thousand phlebotomine species have been described worldwide, although in varying languages and mostly without standardization of characters and terminology. During the

${ }^{*}$ Corresponding author: jerome.depaquit@univ-reims.fr

SOPS 4 Special Issue - ISOPS IX - International Symposium on Phlebotomine Sandflies.

Invited Editors: Jérôme Depaquit, Bernard Pesson, Denis Augot, James Gordon Campbell Hamilton, Phillip Lawyer, and Nicole Léger

sims $200^{\circ}$

This is an Open Access article distributed under the terms of the Creative Commons Attribution License (http://creativecommons.org/licenses/by/4.0), which permits unrestricted use, distribution, and reproduction in any medium, provided the original work is properly cited. 
Table 1. Suggestion of the characters and the respective terminology used for the description of a new phlebotomine fly species. $\mathrm{L}=$ length; $\mathrm{W}=$ width; $\mathrm{M}=$ male; $\mathrm{F}=$ female $\mathrm{X}=$ include the information.

\begin{tabular}{|c|c|c|c|c|}
\hline Structures & Characters & Measurements & Description & Drawing \\
\hline \multicolumn{5}{|l|}{ Head (MF) } \\
\hline Occiput and clypeus & Distribution of the setae & & & $\mathrm{X}$ \\
\hline Clypeus & & $\mathrm{L}, \mathrm{W}$ & & $\mathrm{X}$ \\
\hline Eyes & & $\mathrm{L}, \mathrm{W}$ & & \\
\hline Eye facets & & & & $\mathrm{X}$ \\
\hline Interantennal suture & & & $\mathrm{X}$ & $\mathrm{X}$ \\
\hline Interocular sutures & & & $X$ & $\mathrm{X}$ \\
\hline \multirow[t]{5}{*}{ Flagellomeres } & $\mathrm{f} 1, \mathrm{f} 2, \mathrm{f} 3, \mathrm{f} 12, \mathrm{f} 13, \mathrm{f} 14$ & $\mathrm{~L}$ & & $\mathrm{X}$ \\
\hline & $\begin{array}{l}\text { Position of the internal and external } \\
\text { ascoids on } \mathrm{fl}\end{array}$ & & $\mathrm{X}$ & $\mathrm{X}$ \\
\hline & Ascoidal formula & & $\mathrm{X}$ & \\
\hline & Number and position of papilla(e) & & $\mathrm{X}$ & $\mathrm{X}$ \\
\hline & Simple setae: position & & $\mathrm{X}$ & $\mathrm{X}$ \\
\hline \multirow[t]{4}{*}{ Palpi } & $\mathrm{p} 1, \mathrm{p} 2, \mathrm{p} 3, \mathrm{p} 4, \mathrm{p} 5$ & $\mathrm{~L}$ & & $\mathrm{X}$ \\
\hline & Palpal formula & & $\mathrm{X}$ & \\
\hline & $\begin{array}{l}\text { p2, p3 - Newstead's sensilla: presence } \\
\text { and position/absence }\end{array}$ & & $\mathrm{X}$ & $\mathrm{X}$ \\
\hline & p3, p4: Numbers of spiniform setae & & $\mathrm{X}$ & $\mathrm{X}$ \\
\hline Labrum-epipharynx & & $\mathrm{L}$ & & $\mathrm{X}$ \\
\hline Hypopharynx $(F)$ & Apical teeth & & $\mathrm{X}$ & $\mathrm{X}$ \\
\hline Maxillary lacinia $(\mathrm{F})$ & External and internal teeth: position & & $\mathrm{X}$ & $\mathrm{X}$ \\
\hline Labium (MF) & Labial suture: open or in furca & & $\mathrm{X}$ & $\mathrm{X}$ \\
\hline \multirow[t]{5}{*}{ Cibarium (F) } & $\begin{array}{l}\text { Anterior teeth: horizontal/vertical/lateral } \\
\text { position }\end{array}$ & & $\mathrm{X}$ & $\mathrm{X}$ \\
\hline & Posterior teeth: numbers & & $\mathrm{X}$ & $\mathrm{X}$ \\
\hline & Lateral teeth: presence/absence & & $\mathrm{X}$ & $\mathrm{X}$ \\
\hline & Sclerotized arch & & $\mathrm{X}$ & $\mathrm{X}$ \\
\hline & Sclerotized area & & $\mathrm{X}$ & $\mathrm{X}$ \\
\hline Pharynx (MF) & Teeth: presence/absence & & $\mathrm{X}$ & $\mathrm{X}$ \\
\hline \multicolumn{5}{|l|}{ Cervix (MF) } \\
\hline Cervical sensilla & Number & & $\mathrm{X}$ & \\
\hline Ventro-cervical sensilla & Presence/absence & & $\mathrm{X}$ & \\
\hline Thorax (MF) & & $\mathrm{L}$ & & \\
\hline Sclerites & Coloration & & $\mathrm{X}$ & \\
\hline Mesonotum & Post-alar setae: presence/absence & & $\mathrm{X}$ & \\
\hline \multirow[t]{8}{*}{ Pleural sclerites } & Paratergital setae: presence/absence & & $\mathrm{X}$ & \\
\hline & Proepimeral setae: presence/absence & & $\mathrm{X}$ & \\
\hline & $\begin{array}{l}\text { Upper anepisiternal setae: presence/ } \\
\text { absence }\end{array}$ & & $\mathrm{X}$ & \\
\hline & $\begin{array}{l}\text { Lower anapisternal setae: presence/ } \\
\text { absence }\end{array}$ & & $\mathrm{X}$ & \\
\hline & Anepimeral setae: presence/absence & & $\mathrm{X}$ & \\
\hline & $\begin{array}{l}\text { Metaepisternal setae: presence (number)/ } \\
\text { absence }\end{array}$ & & $\mathrm{X}$ & \\
\hline & Metaepimeral setae: presence/absence & & $\mathrm{X}$ & \\
\hline & $\begin{array}{l}\text { Setae on the anterior region of the } \\
\text { katepisternum: presence/absence }\end{array}$ & & $\mathrm{X}$ & \\
\hline Suture between mesepimeron and metaepisternum & Presence/absence & & $\mathrm{X}$ & \\
\hline Metafurca: vertical arms & United/separated & & $\mathrm{X}$ & \\
\hline \multirow[t]{2}{*}{ Wing } & $\mathrm{r} 5$ & $\mathrm{~L}$ & & \\
\hline & Alpha, beta, gamma, delta, pi & $\mathrm{L}$ & & \\
\hline \multirow[t]{3}{*}{ Legs } & $\begin{array}{l}\text { Coxa, femur, tibia, tarsomeres (ti, sum } \\
\text { of tii, tiii, tiv, tv) }\end{array}$ & $\mathrm{L}$ & & \\
\hline & Metafemur-spines: presence/absence & & $\mathrm{X}$ & \\
\hline & $\begin{array}{l}\text { Metatarsomere iii number of verticils with } \\
\text { spines }\end{array}$ & & $\mathrm{X}$ & \\
\hline Abdomen & & $\mathrm{L}$ & & \\
\hline Tergites ii-v (MF) & Setae forming or not two bands & & $\mathrm{X}$ & \\
\hline Tergites ii-vii (M) & Tergal papillae: presence/absence & & $\mathrm{X}$ & \\
\hline
\end{tabular}


Table 1. (continued)

\begin{tabular}{|c|c|c|c|c|}
\hline Structures & Characters & Measurements & Description & Drawing \\
\hline \multicolumn{5}{|l|}{ Genitalia (M) } \\
\hline & Clusters of setae: presence and position/absence & $\mathrm{L}, \mathrm{W}$ & $\mathrm{X}$ & $\mathrm{X}$ \\
\hline & Sclerotized band in the ventral margin/presence/absence & & $\mathrm{X}$ & $\mathrm{X}$ \\
\hline Gonostyle & & $\mathrm{L}$ & & \\
\hline & Spines: number, position, and aspects (size and thickness) & & $\mathrm{X}$ & $\mathrm{X}$ \\
\hline Parameres & Dorsal and ventral margin & $\mathrm{L}$ & & \\
\hline & Shape and covering bristle & & $\mathrm{X}$ & $\mathrm{X}$ \\
\hline Parameral sheath & Dorsal and ventral margin & $\mathrm{L}$ & & \\
\hline & Shape & & $\mathrm{X}$ & $\mathrm{X}$ \\
\hline Epandrial lobes & & $\mathrm{L}, \mathrm{W}$ & & \\
\hline & Permanent setae: presence/absence & & & $\mathrm{X}$ \\
\hline Cerci; cercus (sing.) & & $\mathrm{L}, \mathrm{W}$ & & $\mathrm{X}$ \\
\hline Sperm pump & & $\mathrm{L}, \mathrm{W}$ & $X$ & $X$ \\
\hline Ejaculatory apodeme & & $\mathrm{L}, \mathrm{W}$ & $\mathrm{X}$ & $X$ \\
\hline Aedeagal ducts & & $\mathrm{L}$ & $\mathrm{X}$ & $\mathrm{X}$ \\
\hline & Tip shape & & & \\
\hline Hypandrial apodemes & Presence/absence & & $\mathrm{X}$ & $X$ \\
\hline Genitalia $(\mathrm{F})$ & & & & \\
\hline VIII tergite & Setae: presence (number)/absence & & $\mathrm{X}$ & $\mathrm{X}$ \\
\hline IX tergite & Protuberance: presence/absence & & $\mathrm{X}$ & $\mathrm{X}$ \\
\hline Spermathecae & Shape & $\mathrm{L}$ & & \\
\hline Terminal knob & Shape & & $\mathrm{X}$ & $\mathrm{X}$ \\
\hline Spermathecal individual ducts & Aspects: sclerotization, striation & $\mathrm{L}, \mathrm{W}$ & $\mathrm{X}$ & $\mathrm{X}$ \\
\hline Spermathecal common duct & Aspects: sclerotization, striation & $\mathrm{L}, \mathrm{W}$ & $\mathrm{X}$ & $\mathrm{X}$ \\
\hline Genital fork & Aspects of chamber and stem & & $\mathrm{X}$ & $X$ \\
\hline Cerci; cercus (sing.) & & $\mathrm{L}, \mathrm{W}$ & & \\
\hline $\mathrm{X}$ sternite & Number of setae & & $\mathrm{X}$ & $\mathrm{X}$ \\
\hline
\end{tabular}

Table 2. Suggested terminology for main characters for the description of a new phlebotomine fly species and the most common synonyms; French and Portuguese translations.

\begin{tabular}{|c|c|c|c|}
\hline Suggested terminology & Synonyms & French & Portuguese \\
\hline Head & & Tête & Cabeça \\
\hline Flagellomeres FI-FXIV & $\begin{array}{l}\text { Antennomeres AIII-AXVI, } \\
\text { antennal segments 3-16 }\end{array}$ & $\begin{array}{l}\text { Antennomères; segments antennaires } \\
\text { a3-a16, articles antennaires AIII-AXVI }\end{array}$ & $\begin{array}{l}\text { Antenômeros, segmentos } \\
\text { antenais, artículos antenais }\end{array}$ \\
\hline Ascoids & Geniculated spines & Ascoïdes; épines géniculées & Ascóides, espinhos geniculados \\
\hline Antennal formula & & Formule antennaire & Fórmula antenal \\
\hline Papilla(e) & $\begin{array}{l}\text { Hirsute glands; sensorial } \\
\text { papillae }\end{array}$ & Sensilles & Papilas \\
\hline Newstead's sensilla & $\begin{array}{l}\text { Newstead's spines; } \\
\text { Newstead's sensory spines; } \\
\text { Newstead's modified } \\
\text { spines; hyaline sensilla }\end{array}$ & $\begin{array}{l}\text { Épines de Newstead, sensilles } \\
\text { de Newstead }\end{array}$ & $\begin{array}{l}\text { Espinhos de Newstead, sensilas } \\
\text { de Newstead }\end{array}$ \\
\hline Cibarium & & Cibarium, cavité buccale & Cibário,cavidade bucal \\
\hline Cibarial armature & & Armature cibariale & Armadura cibarial \\
\hline Posterior teeth & Horizontal teeth & Dents cibariales & $\begin{array}{l}\text { Dentes horizontais, dentes } \\
\text { posteriores }\end{array}$ \\
\hline Anterior teeth & Vertical teeth & Denticules & $\begin{array}{l}\text { Dentes verticais, dentes } \\
\text { anteriores }\end{array}$ \\
\hline Sclerotized arch & Chitinous arch & Arc chitineux & $\begin{array}{l}\text { Arco esclerosado, arco } \\
\text { esclerotinizado, arco } \\
\text { quitinoso. }\end{array}$ \\
\hline Sclerotized area & $\begin{array}{l}\text { Pigmented area; pigment } \\
\text { patch }\end{array}$ & Plage pigmentée & $\begin{array}{l}\text { Área esclerotinizada, área } \\
\text { esclerosada, área pigmentada, } \\
\text { área quitinizada. }\end{array}$ \\
\hline Pharyngeal teeth & Spines of pharynx & Dents pharyngées & Espinhos da faringe \\
\hline
\end{tabular}


Table 2. (continued)

\begin{tabular}{|c|c|c|c|}
\hline Suggested terminology & Synonyms & French & Portuguese \\
\hline Thorax & & Thorax & Tórax \\
\hline Post-alar seta(e) & & Soies rétro-alaires & Cerdas pós-alares \\
\hline Sclerites & & Sclérites & Escleritos \\
\hline Proepimeron & & Proépimère & Proepimero \\
\hline Proepimeral setae & Lower anepisternal setae & Soies mésanepistérnales inférieures & $\begin{array}{l}\text { Cerdas proepimerais, cerdas } \\
\text { anepisternais inferiores }\end{array}$ \\
\hline Anepisternum & Mesanepisternum & Mésanepisterne & Anepisterno \\
\hline Upper anepisternal setae & & Soies mésanepistérnales supérieures & Cerdas anepisternais superiores \\
\hline Lower anapisternal setae & & Soies mésanepistérnales inférieures & Cerdas anepisternais inferiores \\
\hline Abdomen & & Abdomen & Abdômen, Abdome \\
\hline Trumpet glands & & Glandes en trompettes & \\
\hline Tergal papillae & & & Papilas tergais \\
\hline Genitalia (M) & Hypopygium & Genitalia, hypopygium & Genitália, hipopígio \\
\hline Gonocoxite & $\begin{array}{l}\text { Basimere, basistyle; coxite; } \\
\text { proximal segment of upper } \\
\text { gonapophyse; basal } \\
\text { segment of upper } \\
\text { appendages; superior } \\
\text { clasper }\end{array}$ & $\begin{array}{l}\text { Coxite; gonocoxite; gonapophyse } \\
\text { supérieure }\end{array}$ & $\begin{array}{l}\text { Basistilo, gonocoxito, coxito, } \\
\text { segmento proximal da } \\
\text { gonapófise superior, segmento } \\
\text { basal do apêndice superior, } \\
\text { claspete superior }\end{array}$ \\
\hline Gonostyle & $\begin{array}{l}\text { Distimere, distal segment of } \\
\text { upper gonapophyses; } \\
\text { terminal segment of upper } \\
\text { appendages; terminal } \\
\text { segment of clasper; style }\end{array}$ & Style, gonostyle & Dististilo, gonóstilo \\
\hline Parameres & $\begin{array}{l}\text { Intermediate appendages; } \\
\text { intermediate } \\
\text { gonapophyses; claspers; } \\
\text { claspette, middle } \\
\text { appendages; }\end{array}$ & Paramère; appendice intermédiaire & $\begin{array}{l}\text { Parâmeros, apêndices } \\
\text { intermediários, gonapófise, } \\
\text { claspetes, apêndices medianos }\end{array}$ \\
\hline Cerci; cercus (sing.) & & Cerques & Cercos \\
\hline Epandrial lobes & $\begin{array}{l}\text { Cerci, lateral lobes; lateral } \\
\text { lobe of IX tergite, lower } \\
\text { gonapophyses, surstyle }\end{array}$ & Cerques, lobes latéraux; surstyles & $\begin{array}{l}\text { Lobos laterais do ix }{ }^{0} \text { tergito, } \\
\text { surstilo, gonapófise inferior }\end{array}$ \\
\hline Sperm pump & $\begin{array}{l}\text { Genital pump; ejaculatory } \\
\text { pump; pompetta }\end{array}$ & Pompe génitale & Bomba ejaculadora, pompeta \\
\hline Ejaculatory apodeme & Piston; rod & Piston & Pistão \\
\hline Sperm sac & $\begin{array}{l}\text { Sac of pompetta, seminal } \\
\text { pump }\end{array}$ & Pavillon de la pompe & Câmara ejaculadora \\
\hline Aedeagal ducts & $\begin{array}{l}\text { Aedeagal filaments; } \\
\text { aedeagus; ejaculatory } \\
\text { ducts; ejaculatory } \\
\text { filaments genital filaments; } \\
\text { spicules; intromitent organ, } \\
\text { penal filaments }\end{array}$ & $\begin{array}{l}\text { Filaments génitaux; canaux } \\
\text { éjaculateurs; organes intromittents; } \\
\text { filaments péniens }\end{array}$ & $\begin{array}{l}\text { Espículos, filamentos penianos, } \\
\text { filamentos ejaculadores, dutos } \\
\text { ejaculadores, órgão } \\
\text { intromitente }\end{array}$ \\
\hline Parameral sheath & $\begin{array}{l}\text { Aedeagal sheath; aedeagus; } \\
\text { gubernaculum; penial } \\
\text { valve; penis, penal theca }\end{array}$ & $\begin{array}{l}\text { Édéage, fourreau pénien; gaine du } \\
\text { pénis; pénis; valve pénienne. }\end{array}$ & $\begin{array}{l}\text { Edeago, pênis, gubernáculo, } \\
\text { valva peniana, teca peniana }\end{array}$ \\
\hline Hypandrial apodemes & $\begin{array}{l}\text { Gonocoxal hypandrial } \\
\text { apodeme of the aedeagal } \\
\text { sheath; sclerotized rods }\end{array}$ & Baguettes abdominales & Hastes esclerosadas \\
\hline \multicolumn{4}{|l|}{ Genitalia (F) } \\
\hline Spermatheca & Body of spermatheca & $\begin{array}{l}\text { Spermathèque; corps de la } \\
\text { spermathèque }\end{array}$ & Corpo da espermateca \\
\hline Terminal knob & Head of the spermatheca & Tête de la spermathèque & Cabeça da espermateca \\
\hline Spermathecal ducts & Ducts & Conduits des spermathèques & Dutos das espermatecas \\
\hline Genital fork & Genital furca & Furca génitale & Furca genital \\
\hline
\end{tabular}




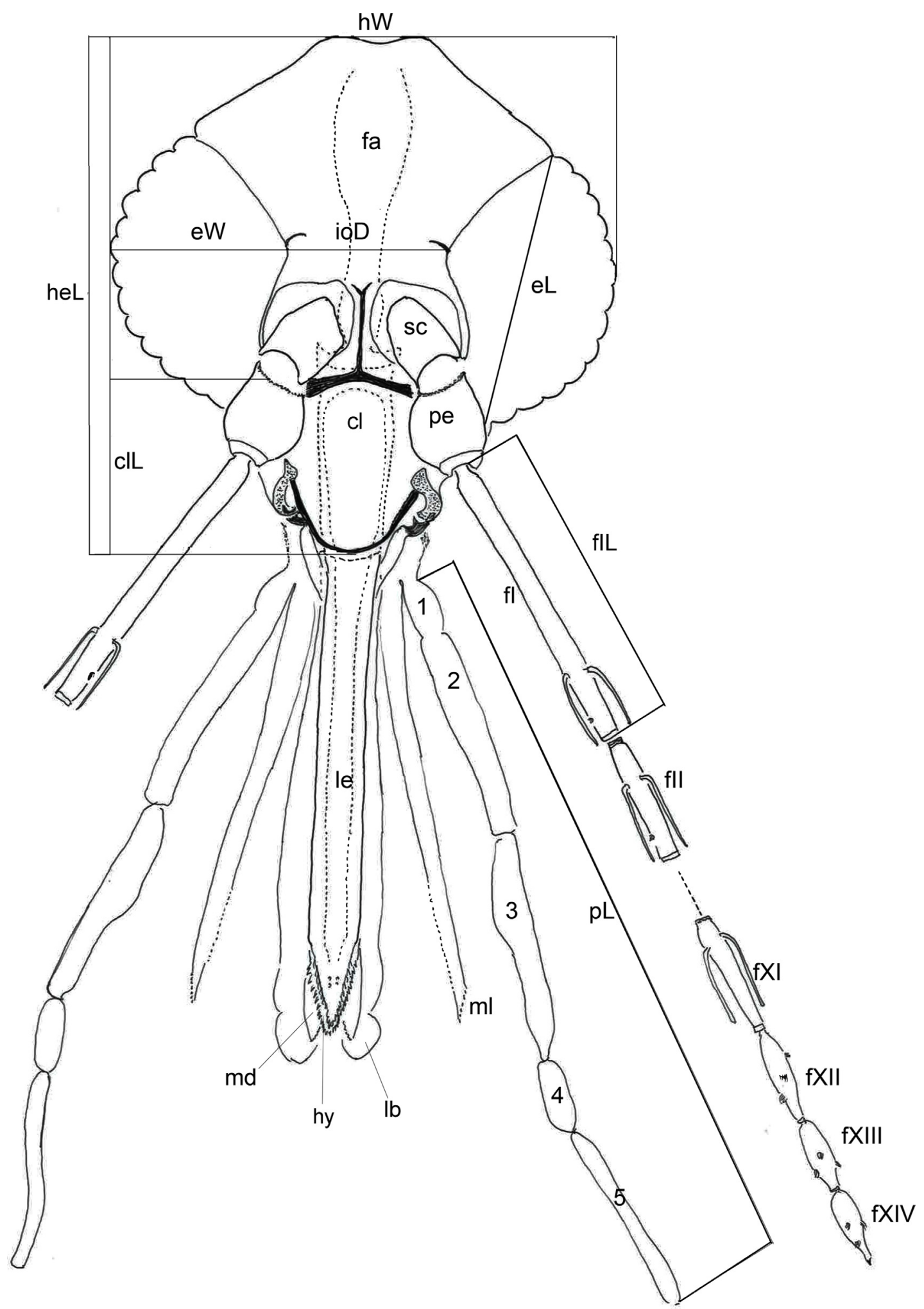

Figure 1. Dorsal view of the head and its appendages of a phlebotomine female: cl - clypeus; fI - 1st flagellomere; fII - 2nd flagellomere; hy - hypopharynx; $\mathrm{ml}$ - maxillary lacinia; lb - labium; le - labrum-epipharynx; md - mandible; pe - pedicel; pha - pharynx; p1 - 1st palpal segment; p2 - 2nd palpal segment; p3 - 3rd palpal segment; p4 - 4th palpal segment; p5 - 5th palpal segment; sc - scape; most frequently used measurements: eL - eye length; eW - eye width; clL - clypeus length; fIL - 1st flagellomere length; heL - head length; hW - head width; ioD - interocular distance; $\mathrm{pL}$ - palpus length - Nyssomyia intermedia. 

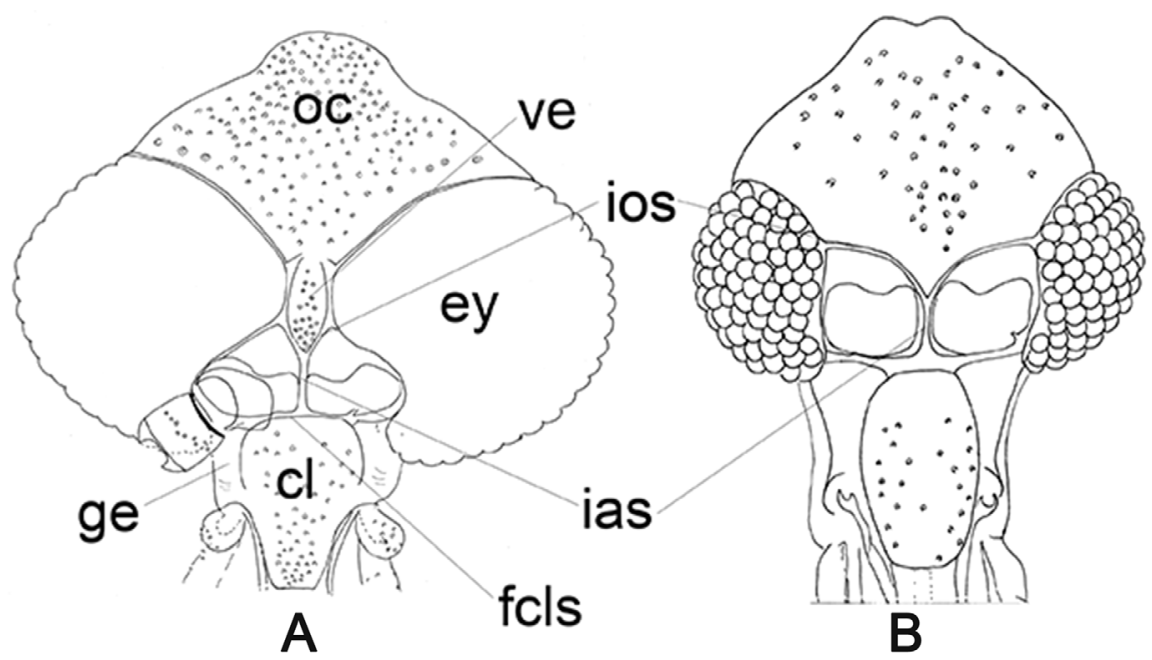

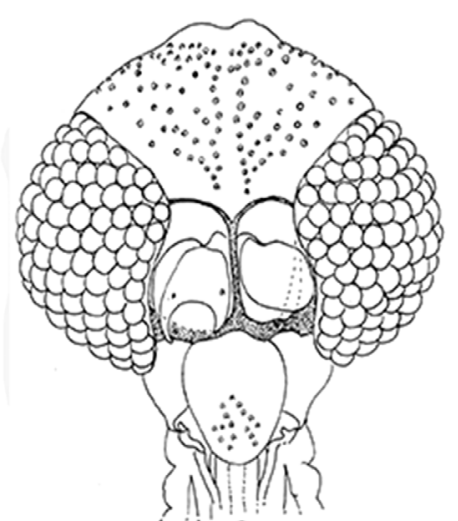

C

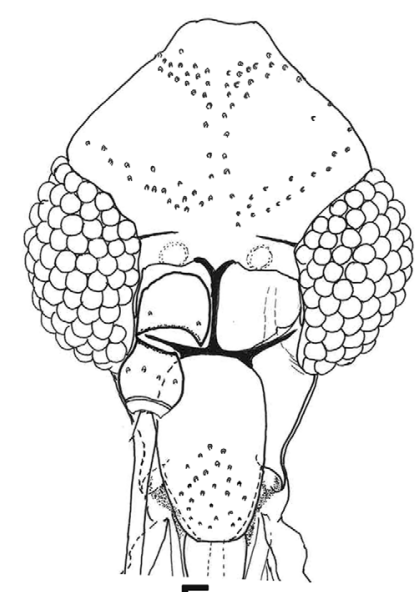

$\mathbf{F}$

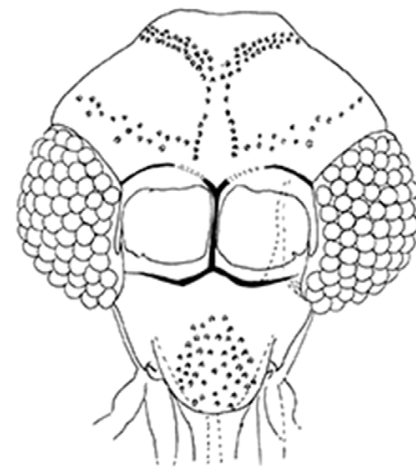

D

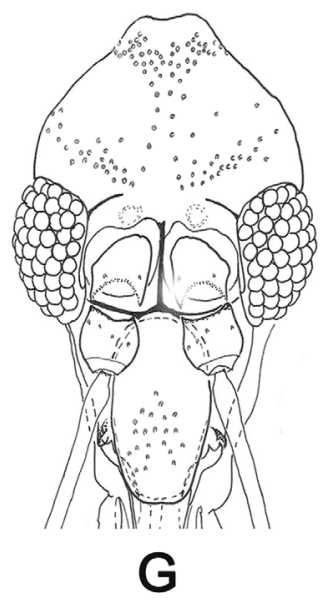

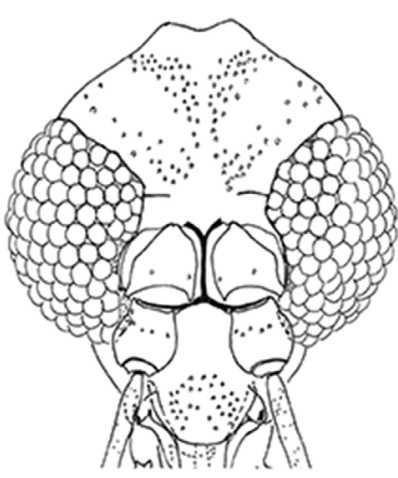

E

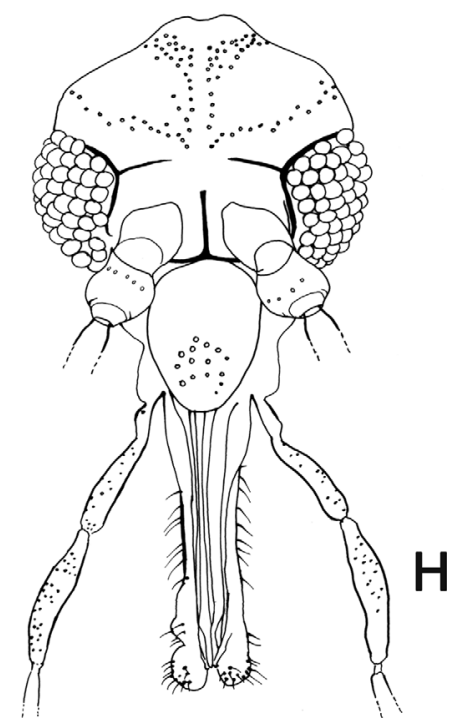

Figure 2. (A-G) Dorsal view of the head of Bruchomyiinae and Phlebotominae with the distribution of the setae on some sclerites, the relation of clypeus to eyes and aspects of some structures (A) Bruchomyiinae (Bruchomyia sp.). (B) Phlebotominae: Warileya phlebotomanica; (C) Brumptomyia brumpti; (D) Sergentomyia (Sergentomyia) minuta; (E) Pintomyia (Pifanomyia) maranonensis; (F) Lutzomyia (Helcocyrtomyia) tejadai; (G) Lu. (Helcocyrtomyia) blancasi; (H) Phlebotomus (Euphlebotomus) barguesae. ey - eye; fcls frontoclypeal suture; ge - gena; ias - interantennal suture; ios - interocular suture; oc - occiput; ve - vertex. 

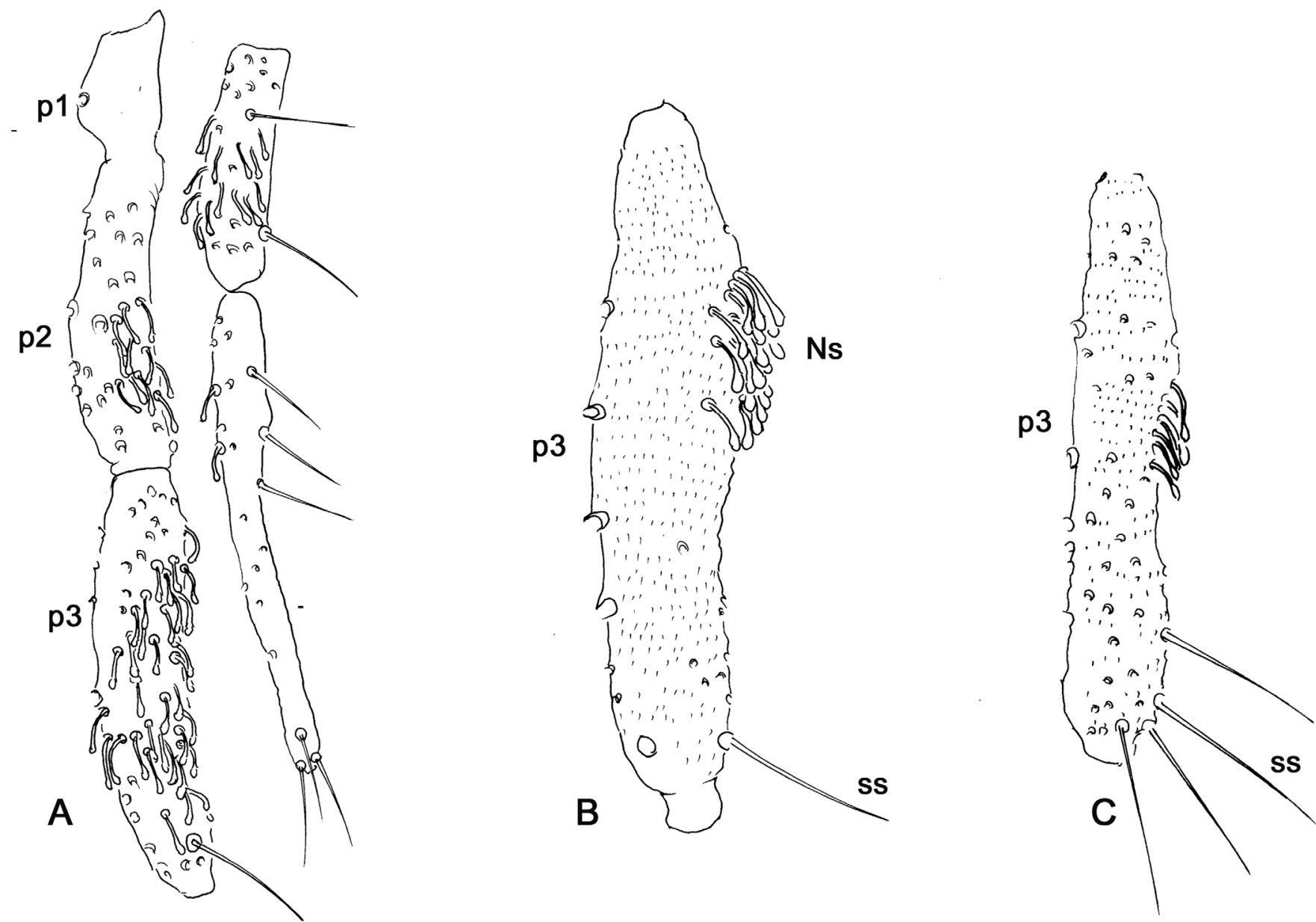

Figure 3. Palpus of Phlebotominae. (A) 1st-5th palpal segments of phlebotomines: Newstead's sensilla (Ns) dispersed on p3 and present from 2nd to 5th segment - Psathyromyia naftalekatzi. (B) Newstead's sensilla concentrated on basal part of the segment and only one simple seta (ss) - Micropygomyia echinathopharynx. (C) Several simple setae on p3 - Warileya phlebotomanica.

Ninth International Symposium on Phlebotomine Sandflies (ISOPS IX) held in Reims from June 28 to July 1, 2016 [4], a round-table on Systematics was co-chaired by EAB Galati, P Lawyer, N Léger, and J Depaquit. We report in this paper the results of discussions on the following topics: the use of the informal term sandflies (or sand flies); methods for permanent preservation and mounting of phlebotomine specimens and appropriate places for deposition of type specimens; a recommendation regarding terms used in morphological descriptions of sand flies and their synonyms, illustrated by several drawings with captions; the characters to be used in taxonomic discussion and to be drawn when a new species is described, and some comments about the systematics of phlebotomines and integrative taxonomy.

\section{On the use of the common name sand flies}

Throughout history, there have been discussions on the use of the popular term sandflies (as one word) or sand flies (two words). Beyond the problem of its true form, this common name has also been applied to other dipterans (e.g. Ceratopogonidae and Simuliidae). Furthermore, some feel that the name does not seem appropriate to the habitat of Neotropical phlebotomine species, whereas others argue that the name was originally given to reflect the color rather than the habitat of these flies. Some colleagues suggested using the term "phlebotomine flies" to replace "sand flies" or "sandflies"; others suggested using "phlebotomine sand flies." The discussion ended without achieving a consensus. 

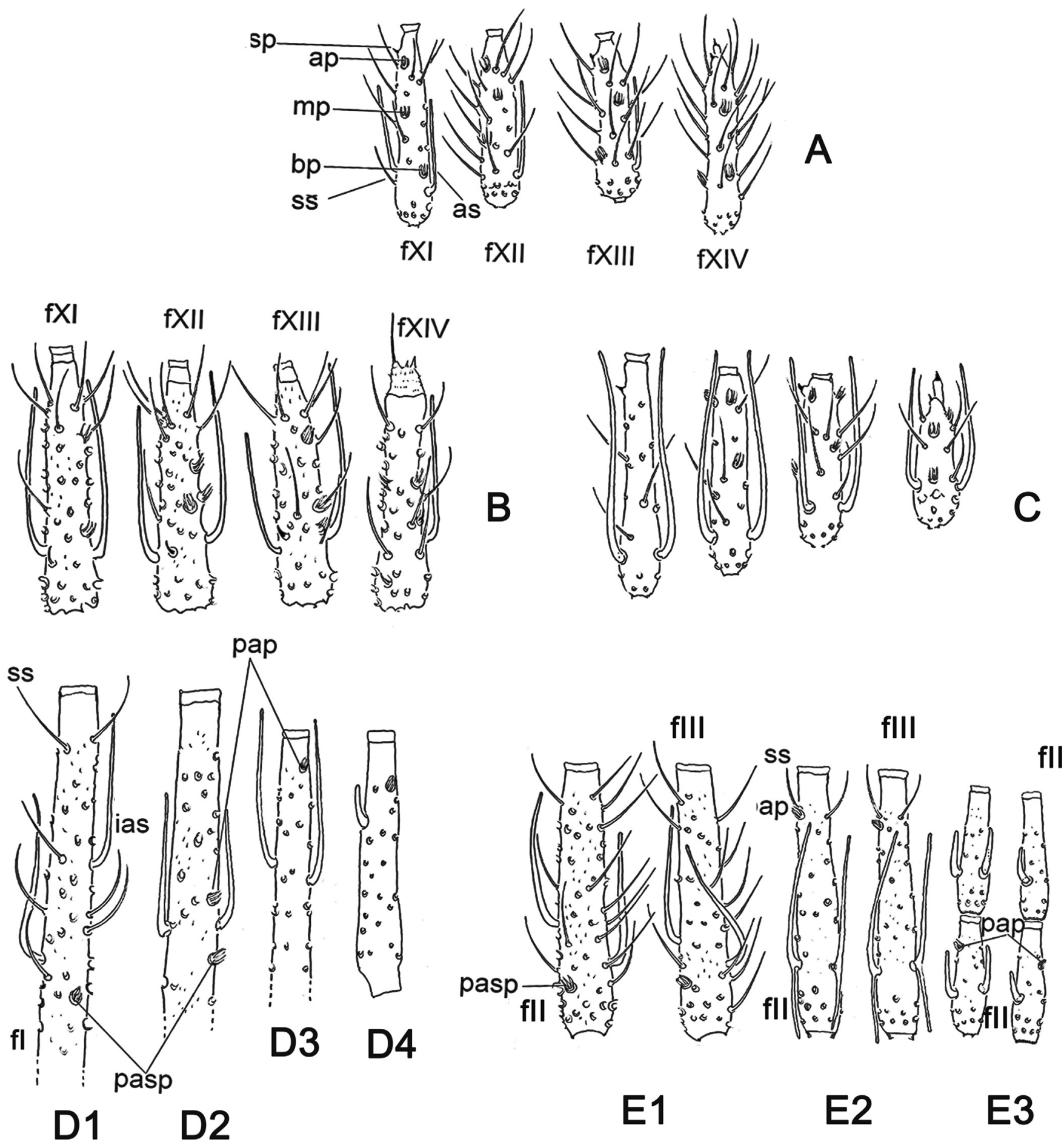

E2

E3

Figure 4. Aspects on the presence and distribution of ascoids, papillae, and simple setae on flagellomeres of Phlebotominae: (A-C) apical flagellomeres (fXI-fXIV): (A) Evandromyia (Barrettomyia) tupynambai (ô); (B) Warileya rotundipennis (P); (C) Trichophoromyia ubiquitalis (+). (D1-D4) First flagellomere (fI) of phlebotomine: (D1) Warileya rotundipennis (†); (D2) Psychodopygus squamiventris ( $९$ );

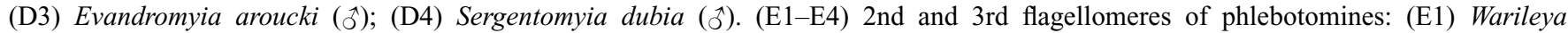
rotundipennis (†); (E2) Psathyromyia shannoni (†); (E3) Sergentomyia dubia (†); (E4) Sergentomyia dubia (仓̂). ap - Apical papilla; as - ascoid; bp - basal papilla; ias - internal ascoid; $\mathrm{mp}$ - median papilla; $\mathrm{p}$ - papilla; pap - preapical papilla; pasp - preascoidal papilla; sp - spiniform papilla; ss - simple seta. 

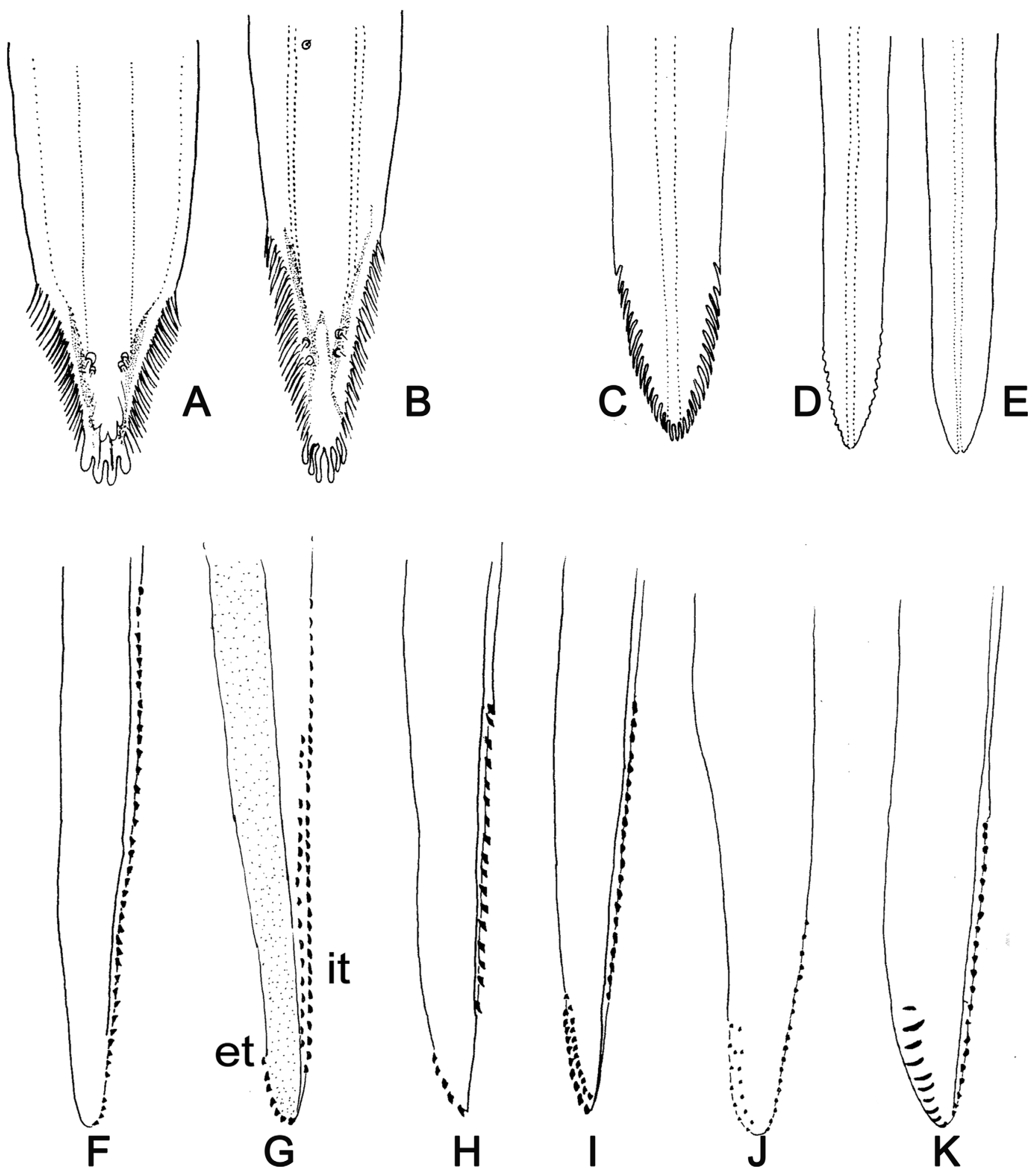

Figure 5. Mouth parts of Phlebotominae. (A, B) Apical region of the labrum-epipharynx of phlebotomine females: (A) Micropygomyia vexator; (B) Lutzomyia longipalpis. (C-E) Apical region of the hypopharynx of phlebotomine females: (C) Lutzomyia longipalpis; (D) Sciopemyia sordellii; (E) Micropygomyia cayennensis. (F-K) Maxillary lacinia of phlebotomine females: (F) Warileya phlebotomanica; (G) Warileya rotundipennis; (H) Lutzomyia cruciata; (I) Nyssomyia intermedia; (J) Micropygomyia quinquefer; (K) Micropygomyia longipennis. et - External teeth of maxillary lacinia; it - internal teeth of maxillary lacinia. 


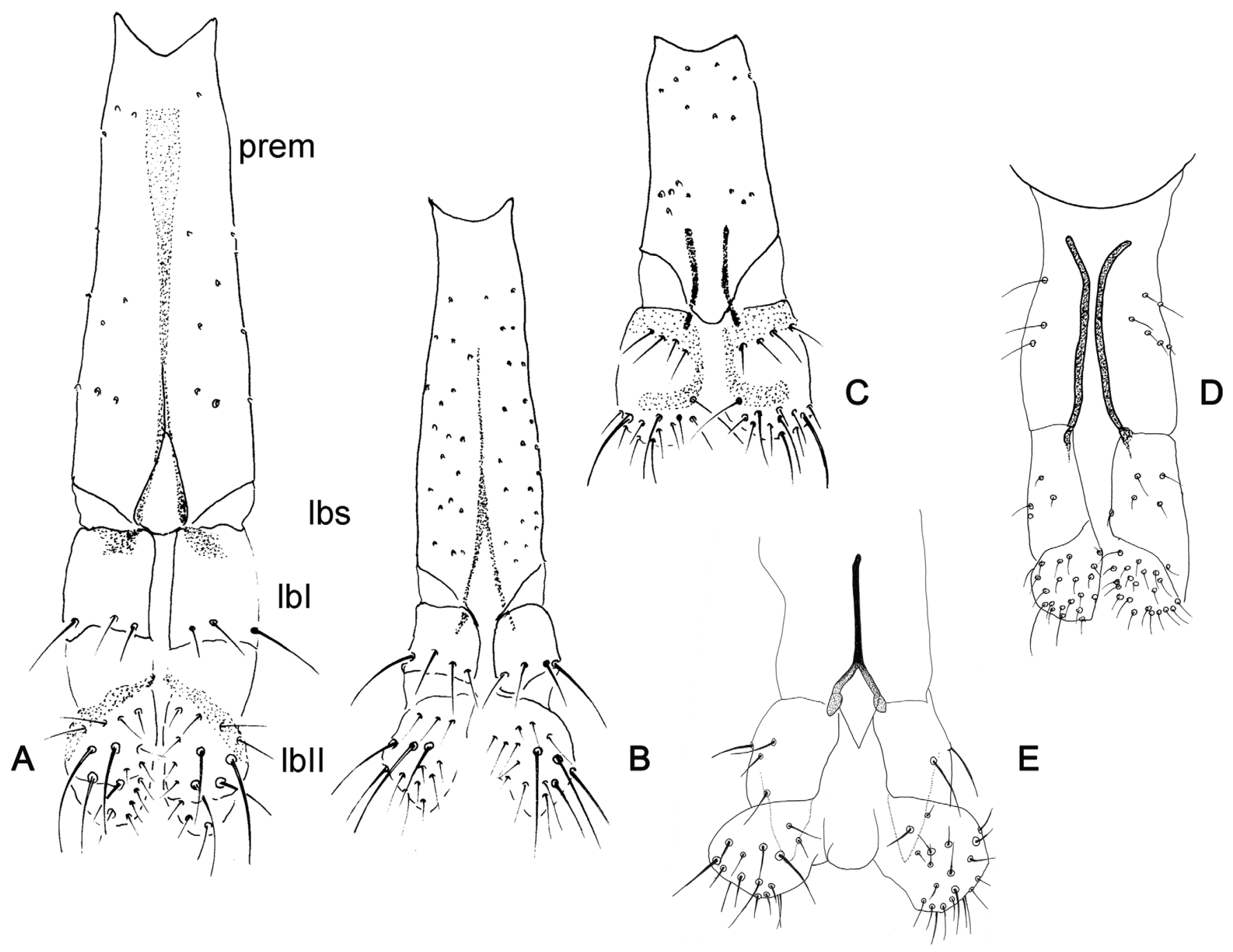

Figure 6. Labium of phlebotomine females in ventral view. (A) Warileya phlebotomanica; (B) Lutzomyia amarali; (C) Sergentomyia minuta; (D) Idiophlebotomus padillarum; (E) Chinius eunicegalatiae. lbI - Labellum I; lbII - labellum II; lbs - labial suture; prem prementum.

\section{On type specimens}

In the past and even more recently, phlebotomine type specimens have been deposited in institutions or schools other than museums $[1,9,10]$. It is very important to deposit at least the holotype in a collection under the supervision of a curator; however, political or administrative changes in these institutions can affect the specimens' preservation and availability under conditions suitable for examination. Consistent with Articles $16 \mathrm{C}$ and $72 \mathrm{~F}$ of the fourth edition of the International Code of Zoological Nomenclature (ICZN), we strongly recommend that authors of species descriptions deposit type and voucher specimens in one or more institutions that maintain a research collection with proper facilities for preserving them and making them accessible for study. It is critical for every institution in which material is deposited to ensure that all name-bearing types are clearly marked and recognizable as such. Moreover, the repository must be capable of taking all necessary steps to preserve these specimens, make them accessible for study, publish lists of name-bearing types in their possession or custody and, in so far as possible, communicate upon request information concerning name-bearing types [6]. In addition to depositing type and voucher specimens, we recommend registration with Zoobank (http://www.zoobank.org) 


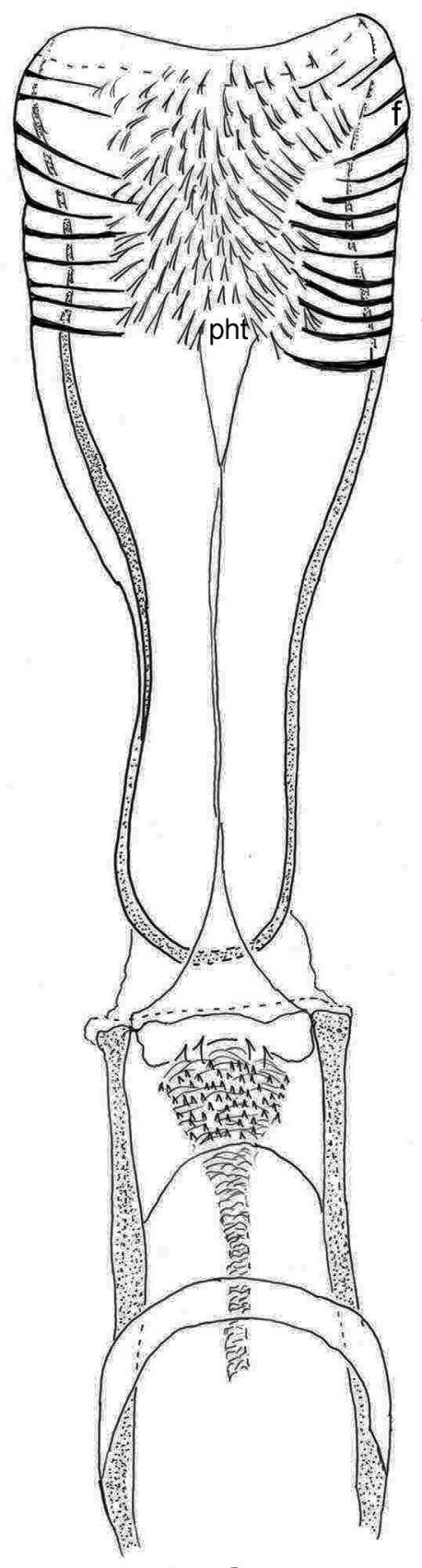

A

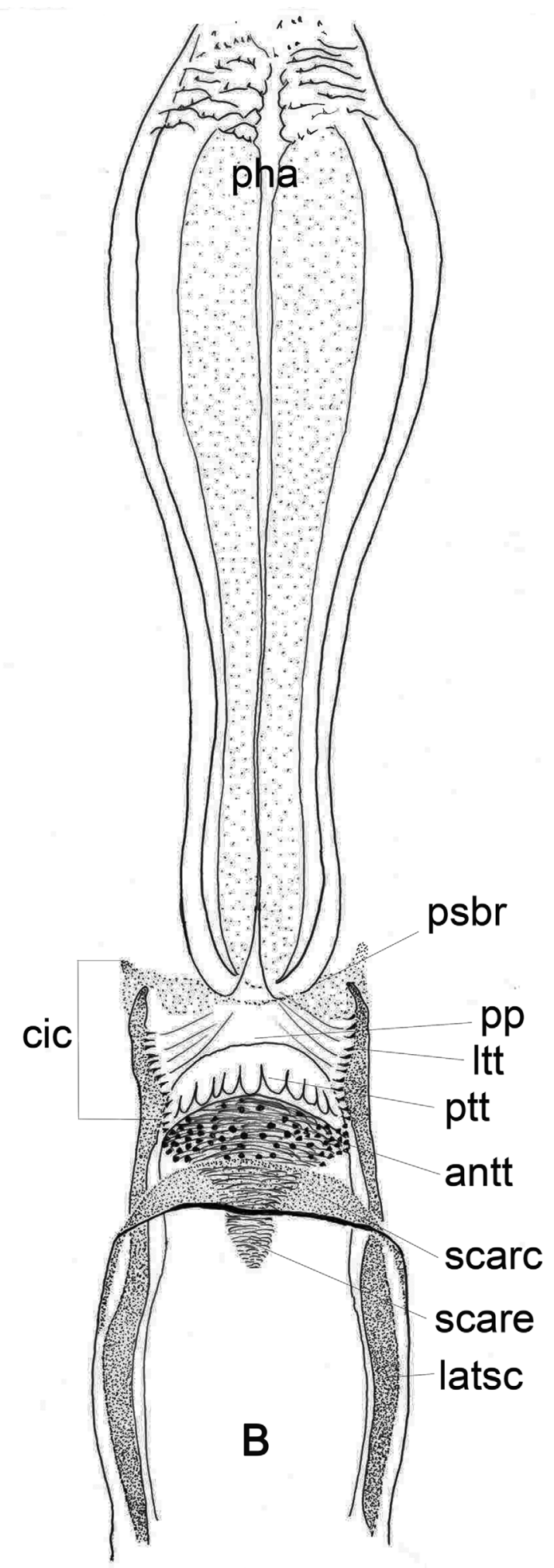

Figure 7. Cibarium and pharynx of phlebotomine females. (A) Micropygomyia atroclavata; (B) Bichromomyia flaviscutellata. antt Anterior teeth; cic - cibarial chamber; $\mathrm{f}$ - fold; ltt - lateral teeth; pha - pharynx; pht - pharyngeal teeth; psbr - posterior bridge; ptt posterior teeth; $\mathrm{pp}$ - posterior protuberance; latsc - lateral sclerite; scarc - sclerotized arch; scare - sclerotized area. 

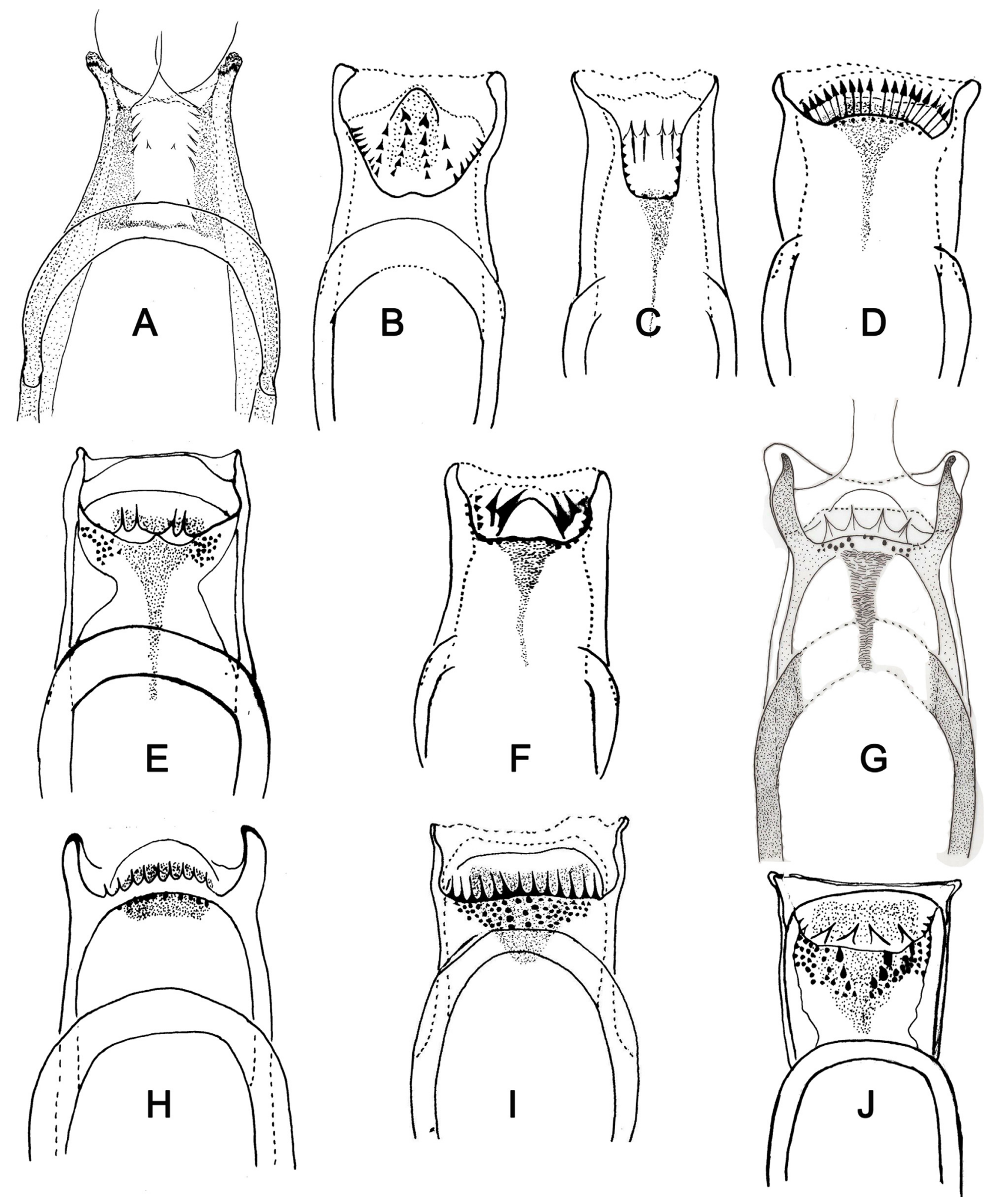

Figure 8. Cibarium of phlebotomine females. (A) Edentomyia piauiensis; (B) Brumptomyia sp; (C) Micropygomyia pilosa; (D) Micropygomyia cayennensis; (E) Evandromyia walkeri; (F) Sciopemyia sordellii; (G) Lutzomyia (Helcocyrtomyia) kirigetiensis; (H) Lutzomyia longipalpis; (I) Trichophoromyia auraensis; (J) Psathyromyia lutziana. 

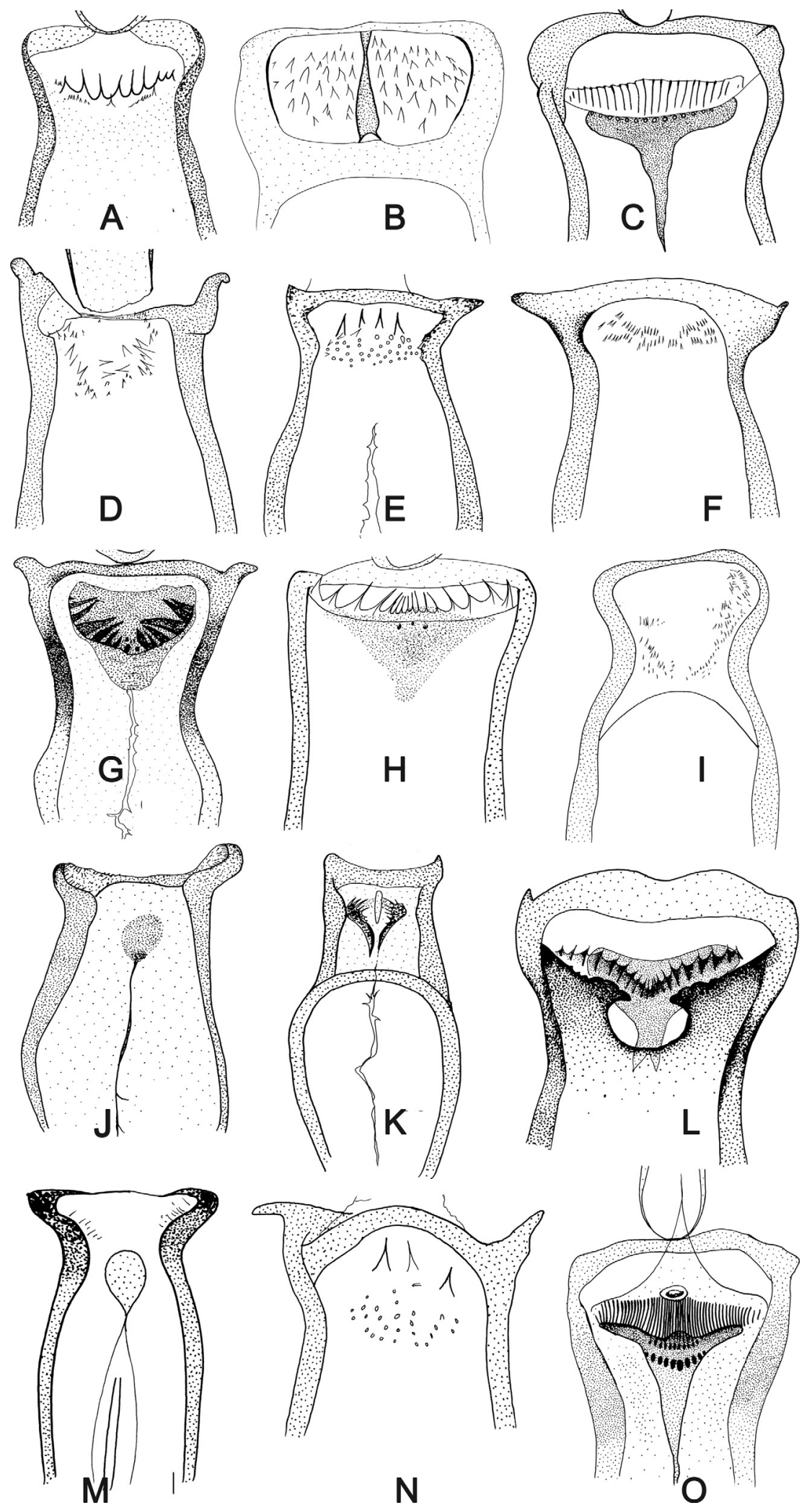

Figure 9. Cibarium of phlebotomine females. (A) Australophlebotomus notteghemae; (B) Idiophlebotomus padillarum; (C) Sergentomyia (Vattieromyia) sclerosiphon; (D) Phlebotomus (Euphlebotomus) mascomai; (E) Phlebotomus (Madaphlebotomus) vaomalalae; (F) Sergentomyia bailyi; (G) Sergentomyia (Sergentomyia) phadangensis; (H) Sergentomyia hivernus; (I) Phlebotomus (Transphlebotomus) anatolicus; (J) Chinius eunicegalatiae; (K) Chinius samarensis; (L) Sergentomyia (Parrotomyia) babu; (M) Parvidens heishi; (N) Phlebotomus (Madaphlebotomus) vincenti; (O) Sergentomyia (Vattieromyia) namo. 


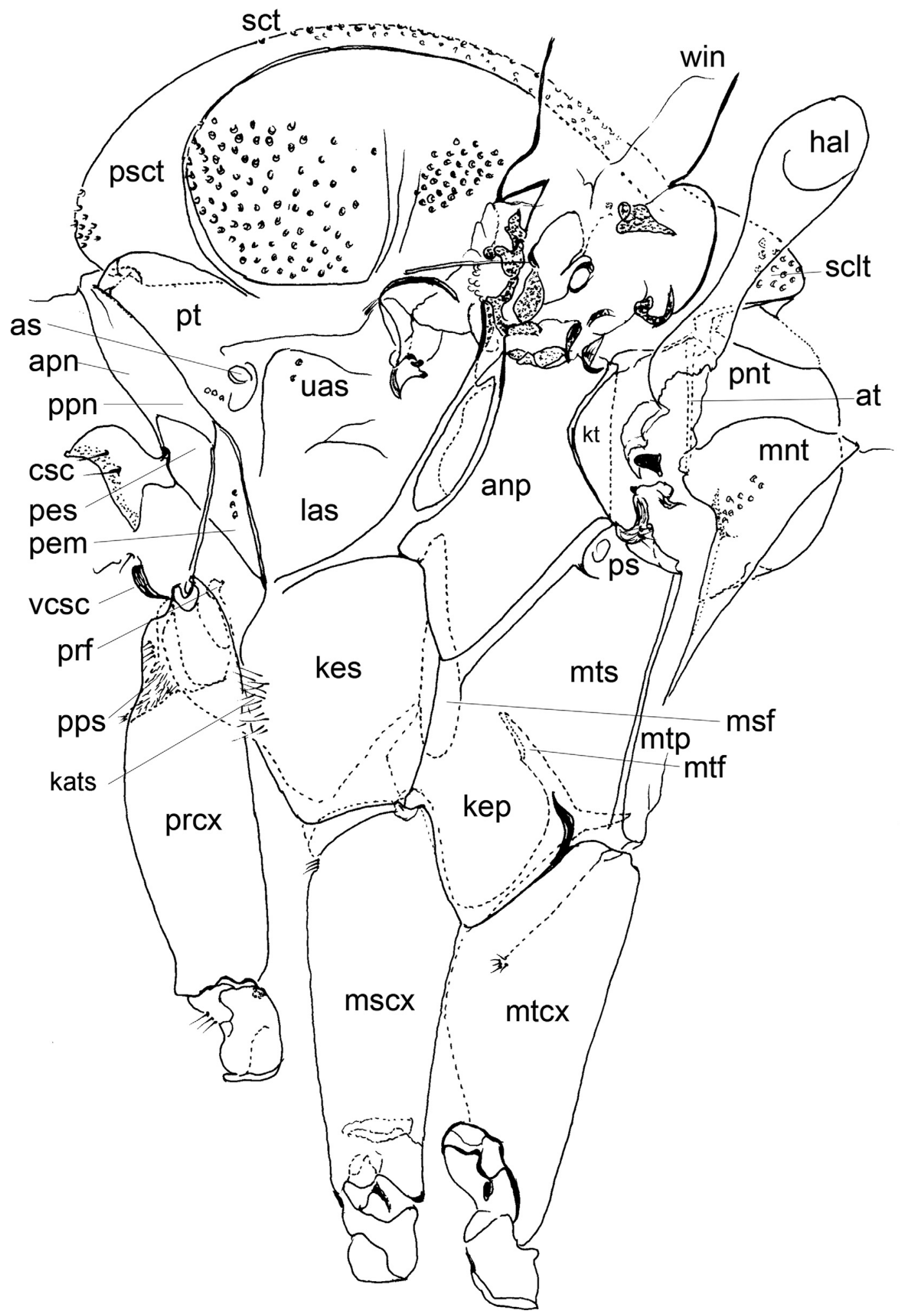

Figure 10. Sclerites of cervix and thorax of Phlebotominae. anp - anepimeron; apn - antepronotum; as - anterior spiracle; at - anatergite; csc - cervical sclerite with a pair of sensilla; hal - halter; kep - katepimeron; kes - katepisternum; kt - katatergitum; las - lower anepisternum; mnt - metanotum; mscx - mesocoxa; msf - mesofurca; mtcx - metacoxa; mtf - metafurca; mtp - metepimeron; mts metepisternum; pem - proepimeron; pes - proepisternum; pnt - postnotum; ppn - postpronotum; pps - protuberance of the prosternum; prcx - procoxa; prf - profurca; ps - posterior spiracle; psct - prescutum; pt - paratergite; sclt - scutellum; sct - scutum; uas - upper anepisternum; vcsc - ventrocervical sclerite; win - wing. Deanemyia samueli. 


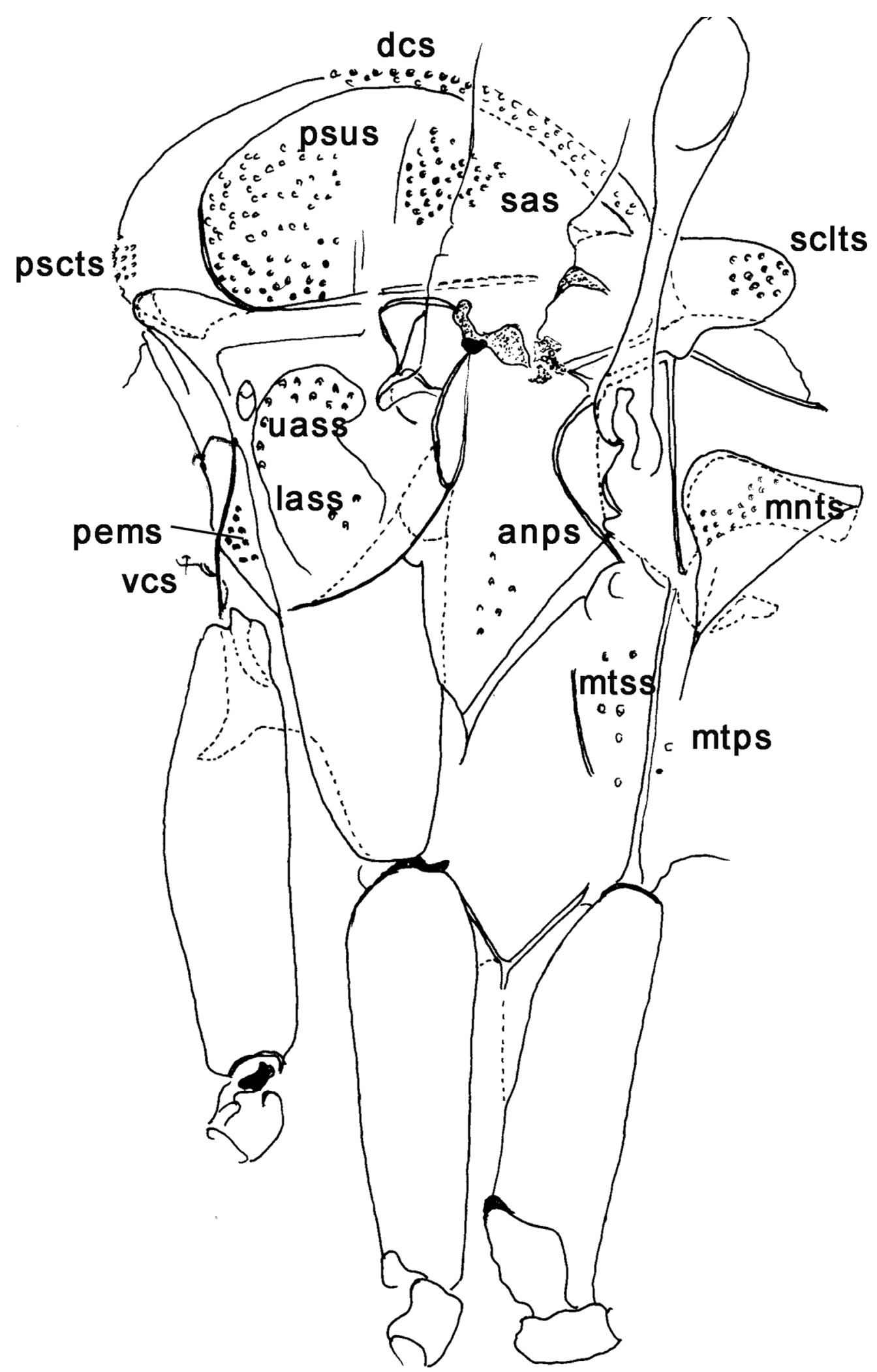

Figure 11. Setae on the thorax of phlebotomines: anps - anepimeral setae; dcs - dorsocentral setae; lass - lower anepisternal setae; mnts metanotal setae; mtps - metepimeral setae; mtss - metepsiternal setae; pems - proepimeral setae; pscts - prescutal setae; psus - postsutural setae; sas - supralar setae; sctls - scutelar setae; uass - upper anepisternal setae; vcs - ventrocervical sensilla. Brumptomyia pintoi. 


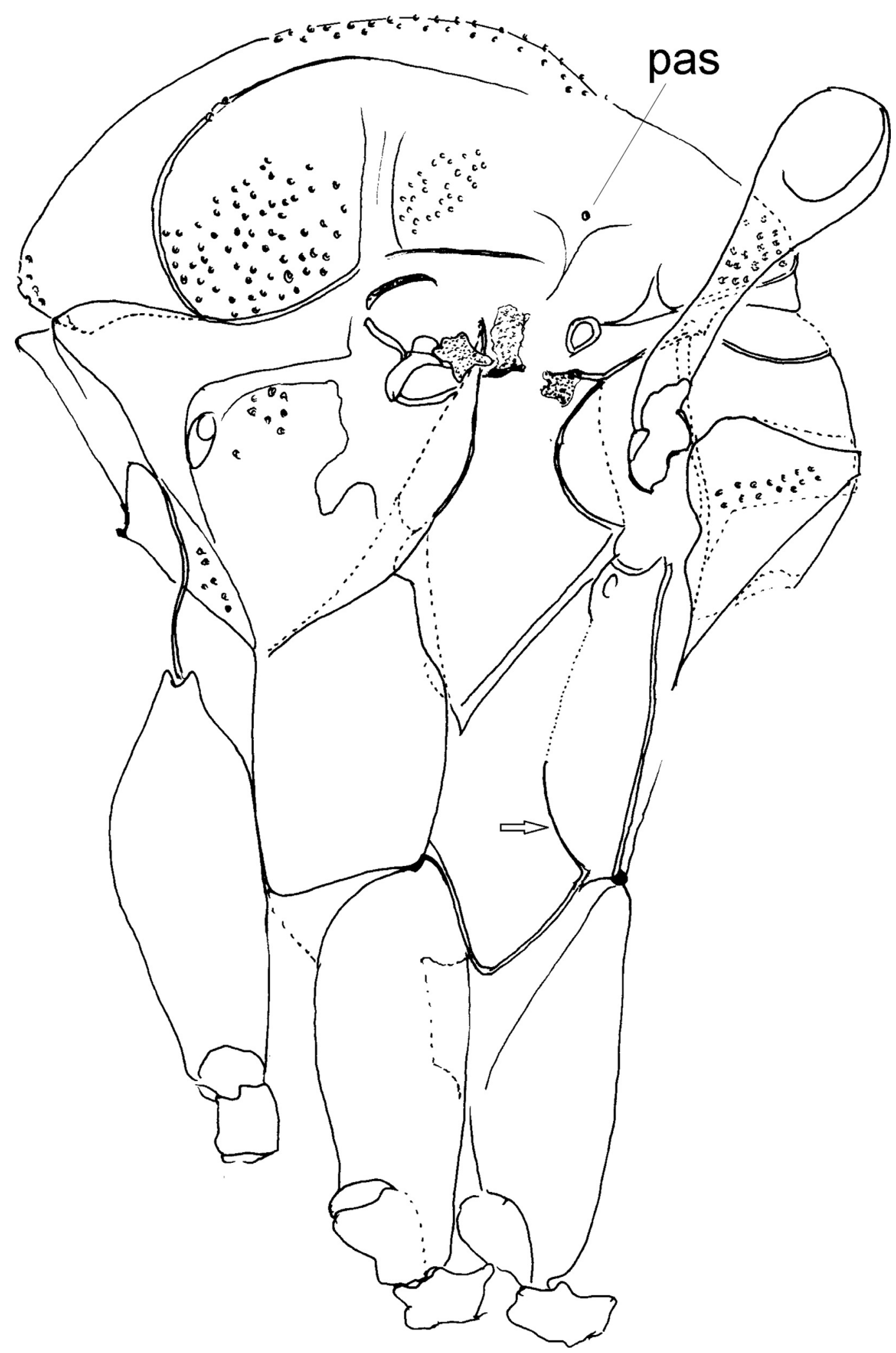

Figure 12. Thorax in lateral view of Phlebotominae with indication of characters in plesiomorphic state: arrow - indicating the long suture separating the katepimeron and metepisternum; pas - postalar seta. Oligodontomyia toroensis. 

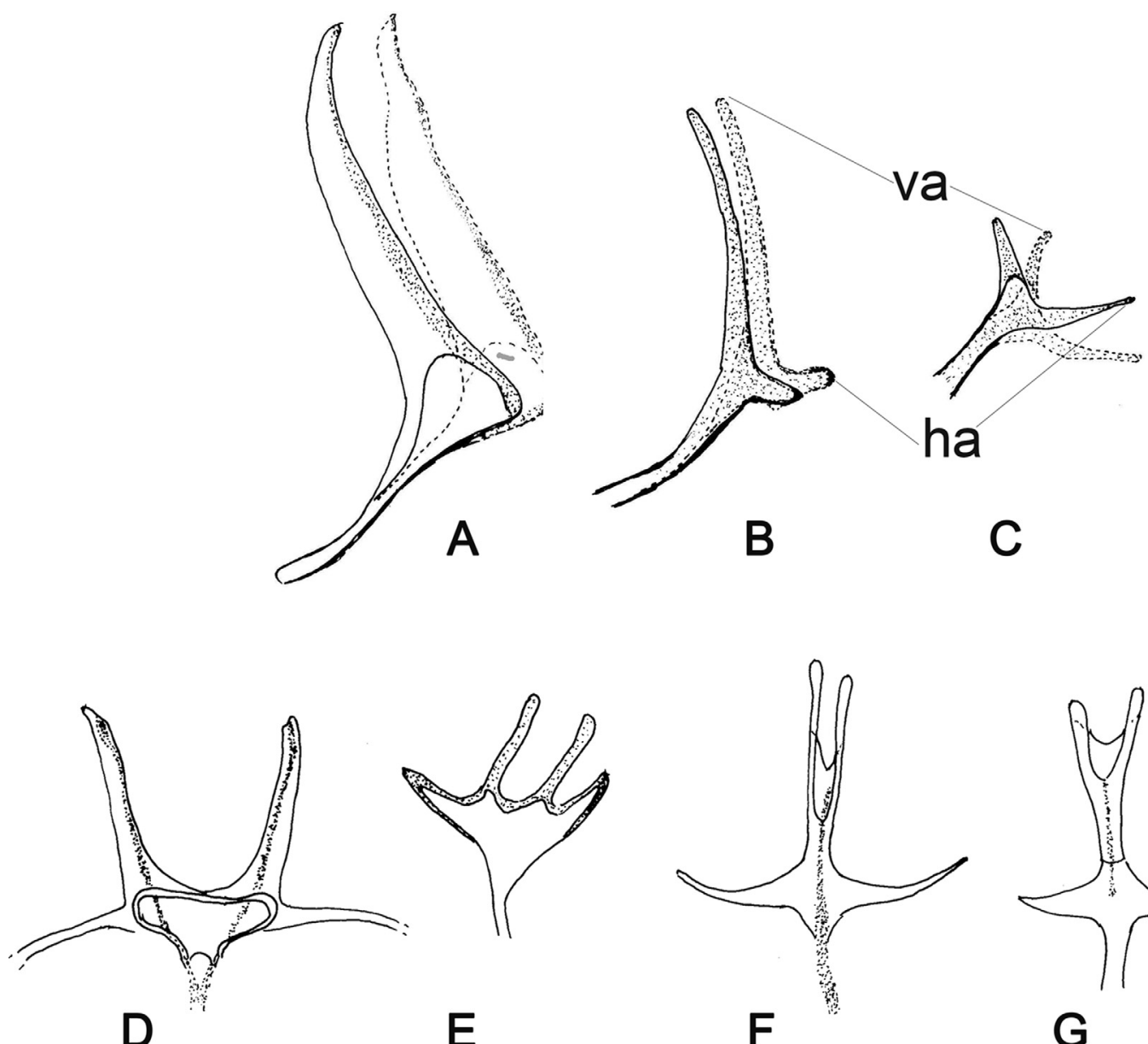

E
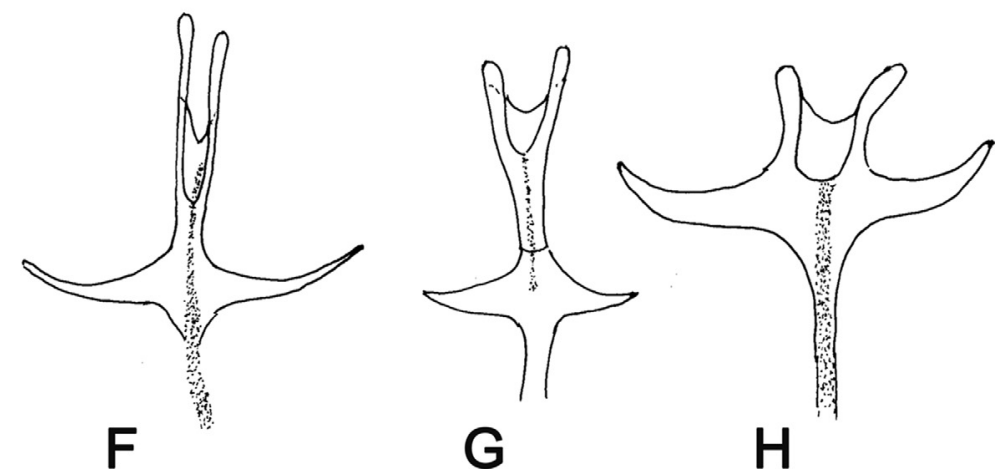

Figure 13. Metafurca of Phlebotominae: (A-C) Lateral view: (A) completely separate vertical arms and atrophied horizontal arms: Warileya phlebotomanica; (B) completely separate vertical arms and short horizontal arms: Warileya nigrosaculla; (C) completely separate vertical arms and long horizontal arms: Chinius samarensis. (D-H) Frontal view: (D) completely separate vertical arms and atrophied horizontal arms: Wa. phlebotomanica; (E) completely separate vertical and short horizontal arms: Chinius eunicegalatiae; (F) united long vertical and horizontal arms: Sergentomyia minuta; (G) united long vertical and short horizontal arms: Bichromomyia flaviscutellata; (H) united short vertical and long horizontal arms: Brumptomyia brumpti.

for all nomenclatural acts (published usages of scientific names of animals, which affect their nomenclature or the typification of a nominal taxon), publications of original taxonomic descriptions, and references to authors and designation of type specimens.

\section{Methods of preserving phlebotomine specimens}

Many type specimens of phlebotomine species and other specimens in many reference collections were mounted in non-permanent media such as Hoyer's Medium or Berlese and have long since deteriorated so that many of the diagnostic characters of the specimens are neither visible nor distinguishable, thereby rendering the specimen useless. It was proposed that a protocol using a permanent medium such as Canada balsam be adopted and standardized, in so far as possible, for preservations of all specimens that are to be deposited in museums for future reference.

\section{Suggested guidelines for the description of new phlebotomine species}

Many pertinent characters of Phlebotominae that are currently used for their identification and classification have 

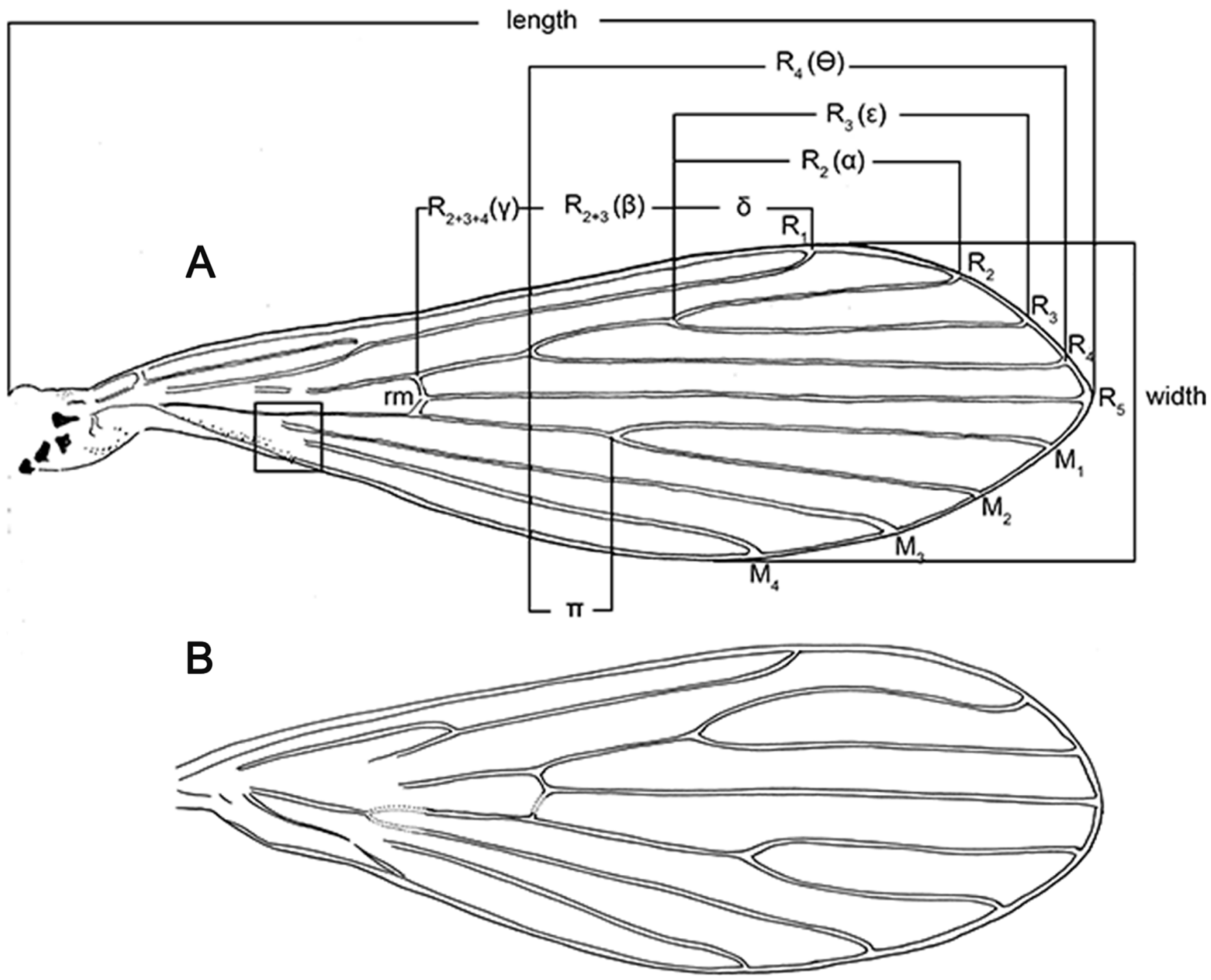

Figure 14. Wing of Phlebotominae. (A) Main indices; (B) wing with of fusion of R2 and R3: Chinius eunicegalatiae.

been described by authors using distinct terminology. This practice has been criticized by other dipterists because, in addition to hindering studies of homology within Phlebotominae, it also makes comparisons among supraspecific taxa difficult. This is particularly problematic for characters of the male terminalia. To this end, we suggest that terminology used in phlebotomine taxonomy be more closely aligned with that used in general dipterology [2, 7]. In order to standardize the descriptions and re-descriptions of phlebotomine species, a list of characters (all body parts and their appendages and sensorial structures, such as spines, setae, papillae, sensilla, sutures, etc.) deserving of comment and illustration is proposed (Table 1). Furthermore, in order to contribute to the standardization of terminology for structures that have been frequently used in phlebotomine taxonomic studies, a list is provided (Table 2) including suggested terms in English and synonyms of these terms that have been used in the past by various authors, in French and Portuguese. Some characters have been infrequently used in published descriptions and may thus be poorly known; for this reason and for the purpose of illustrating the morphological diversity of some characters, drawings have been provided with the corresponding terminology in each legend (Figures 1-28). A drawing is preferable to a photo, but sometimes for structures such as the pharyngeal armature, a photo can supplement or replace a drawing. We posit that the list of characters suggested 


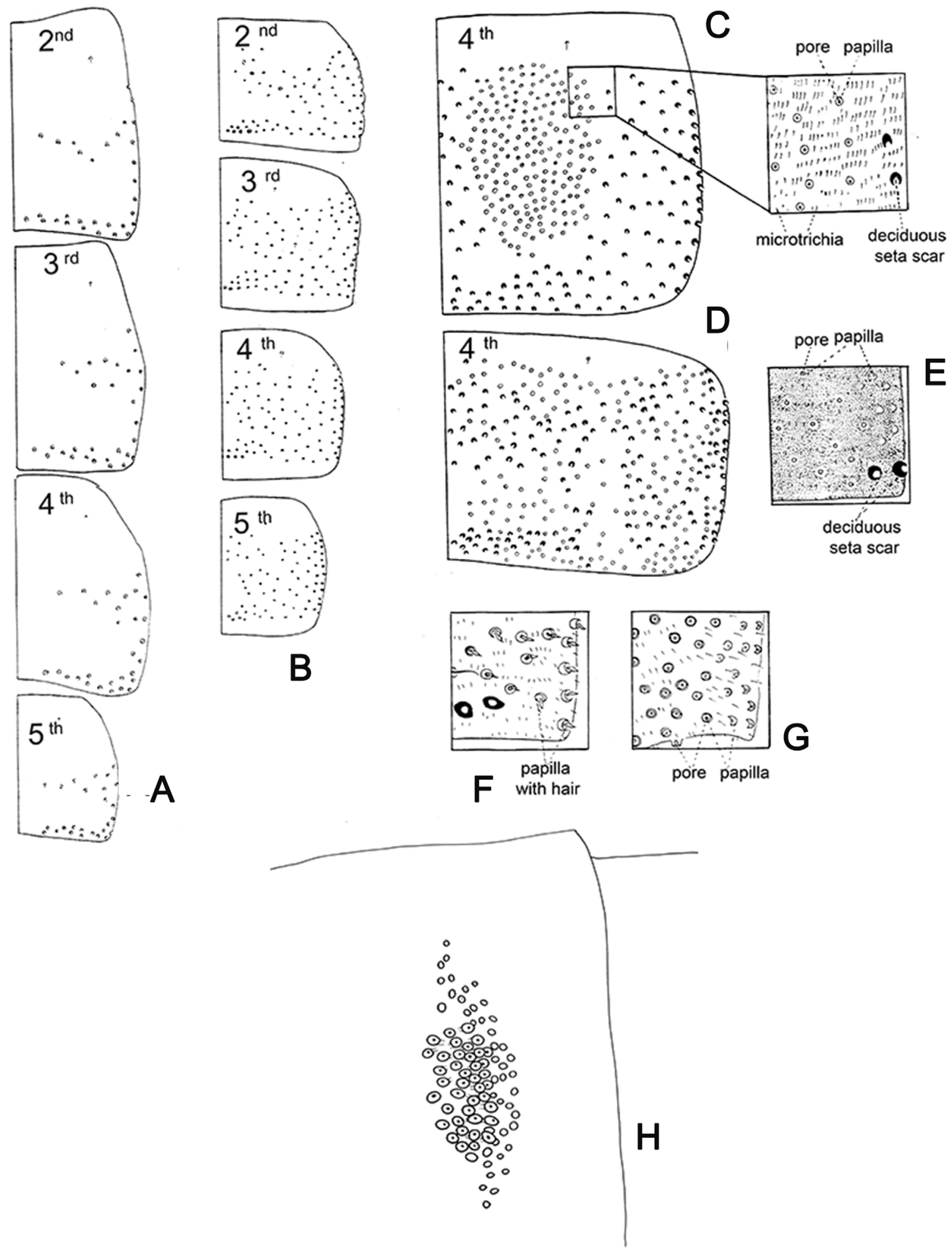

Figure 15. Abdominal tergites of Phlebotominae, showing arrangements of the deciduous bristles and tergal papillae and aspects of the tergal papillae and "trumpets glands". (A, B) 2nd-5th male tergites with the arrangement of the deciduous bristles. (A) Two transverse bands: Warileya phlebotomanica. (B) Randomly: Nyssomyia intermedia. (C, D) Distribution and aspects of the tergal papillae on 4th tergite; (C) restricted to the central area: Lutzomyia longipalpis; (D) dispersed over the surface of the tergite, among the deciduous bristle scars: Pintomyia fischeri. (E-G) Aspects of the papillae on the 6th tergite: (E) papillae without hair and without clear demarcation of their borders; (F) papillae with hair: Brumptomyia cardosoi; $(\mathrm{G})$ papillae without hair and with clear demarcation of their borders: Evandromyia walkeri. (H) "Trumpet glands" of the fourth abdominal tergite: Chinius samarensis. 

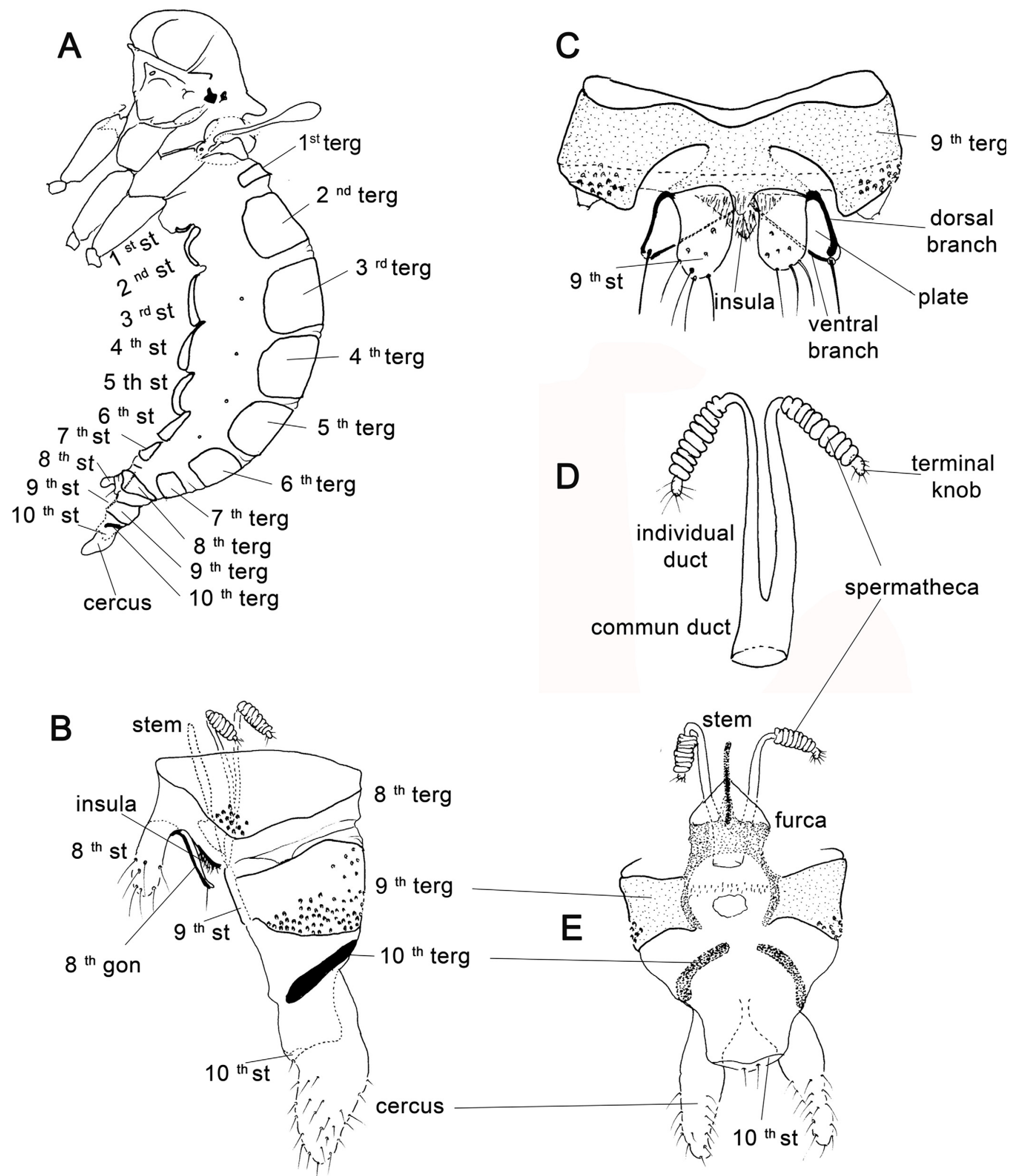

Figure 16. Abdomen and genitalia of Phlebotomine female. (A) abdomen in lateral view; (B) genitalia in lateral view; (C) 8th segment in ventral view; (D) 9th segment, 10th segment and cerci in ventral view. Nyssomyia neivai. gon - gonopod; st - sternite; stem - fork stem; terg - tergite. 


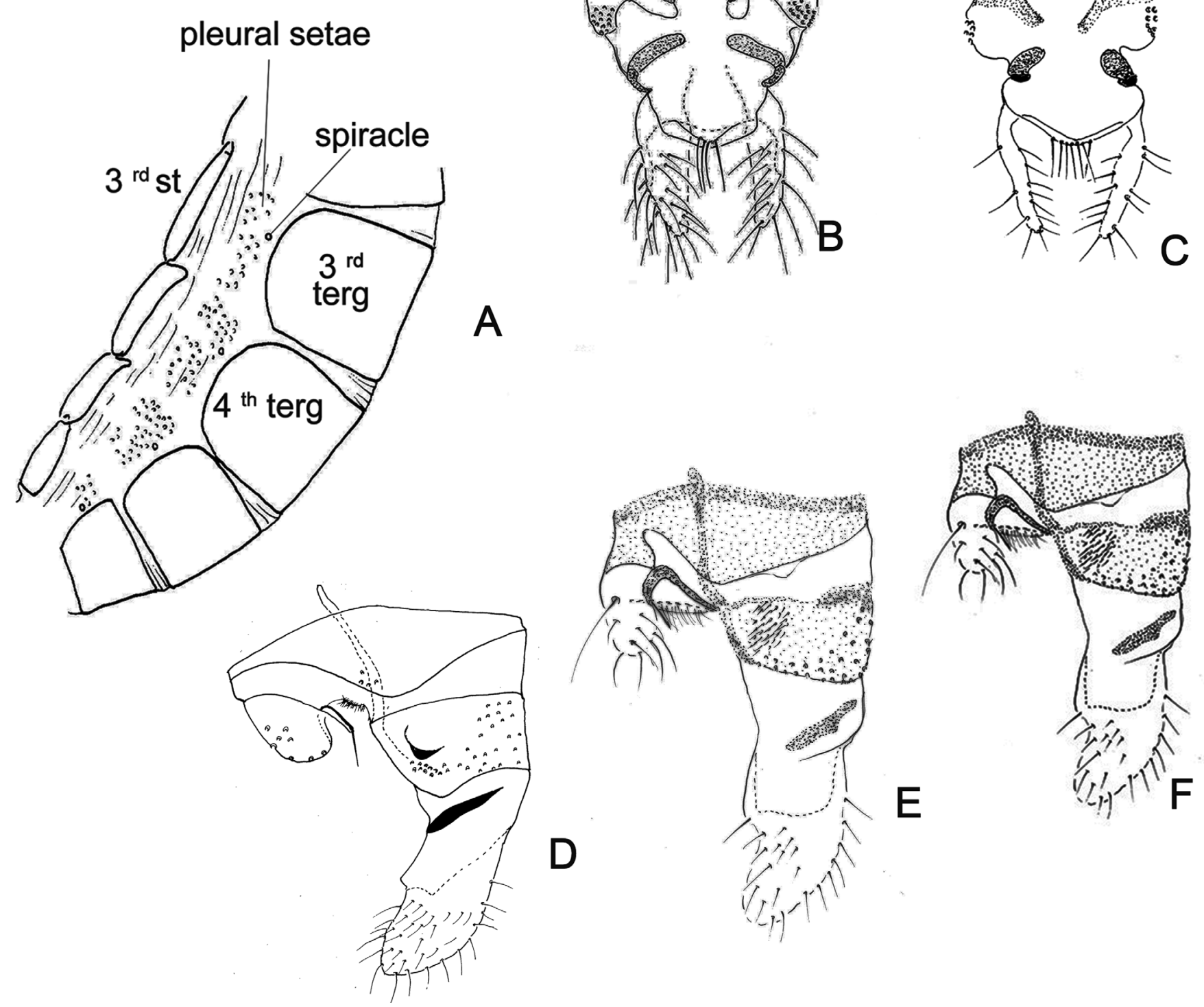

Figure 17. Some structures of the abdomen and the genitalia of phlebotomine females. (A) 3rd-6th abdominal segments showing the pleural setae: Lutzomyia (Tricholateralis) sherlocki. (B, C) 10th sternite showing non-deciduous setae in the median region: (B) Micropygomyia vexator, (C) Sergentomyia minuta. (D) 9th segment showing a sclerotized protuberance on the tergite: Migonemyia (Migonemyia) rabelloi, (E) spicules in 9th and 10th tergites: Lutzomyia (Tricholateralis) cruciata. (F) 9th tergite with short bristles: Sciopemyia sordellii. 

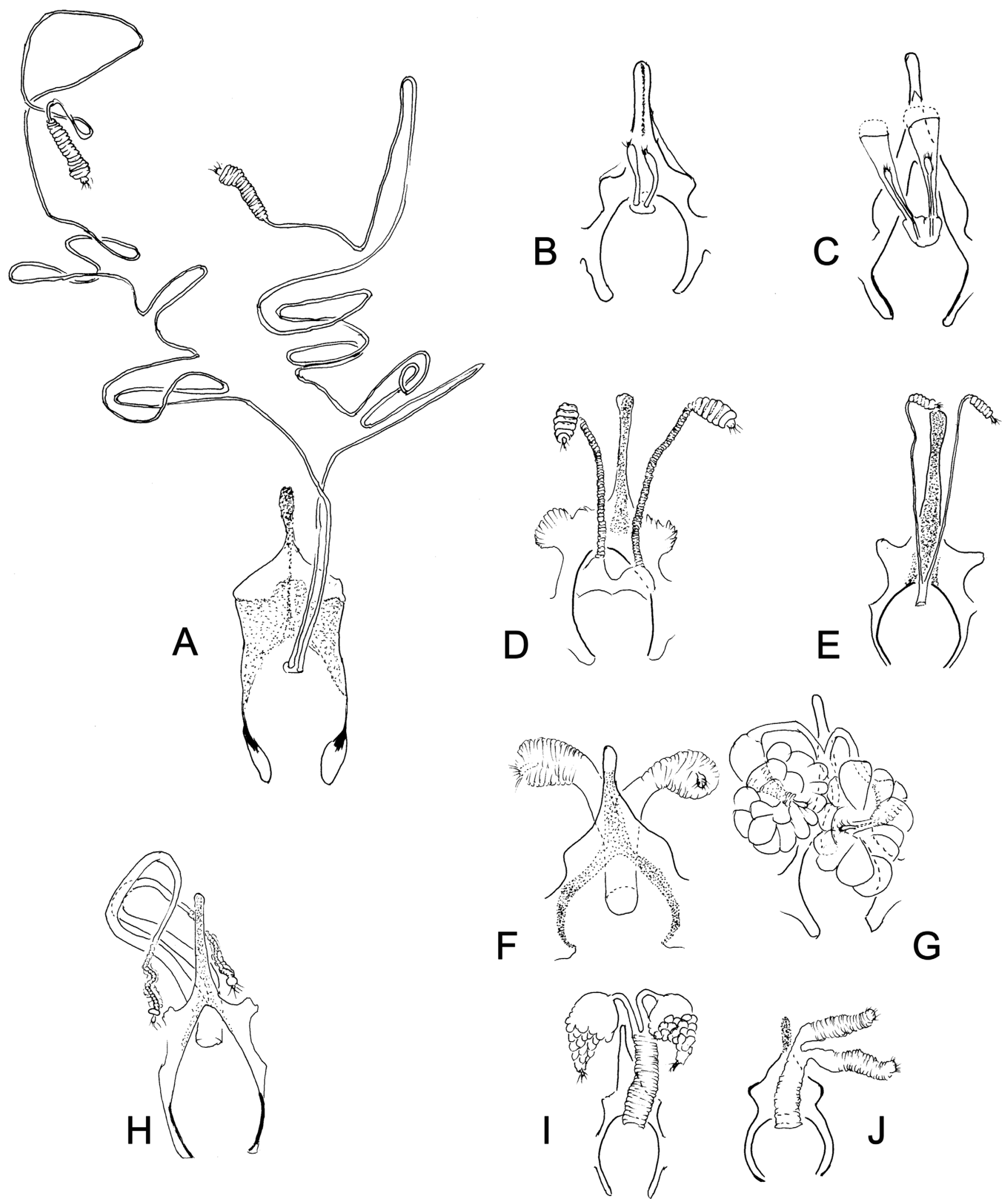

Figure 18. Spermathecae and genital fork aspects of Phlebotominae. (A) Brumptomyia brumpti; (B) Migonemyia (Blancasmyia) gorbitzi; (C) Viannamyia tuberculata; (D) Phlebotomus (Phlebotomus) papatasi; (E) Lutzomyia (Lutzomyia) longipalpis; (F) Dampfomyia (Coromyia) vespertilionis; (G) Dampfomyia (Dampfomyia) anthophora; (H) Micropygomyia (Coquillettimyia) vexator; (I) Evandromyia (Evandromyia) saulensis; (J) Ev. (Eva.) infraspinosa. 


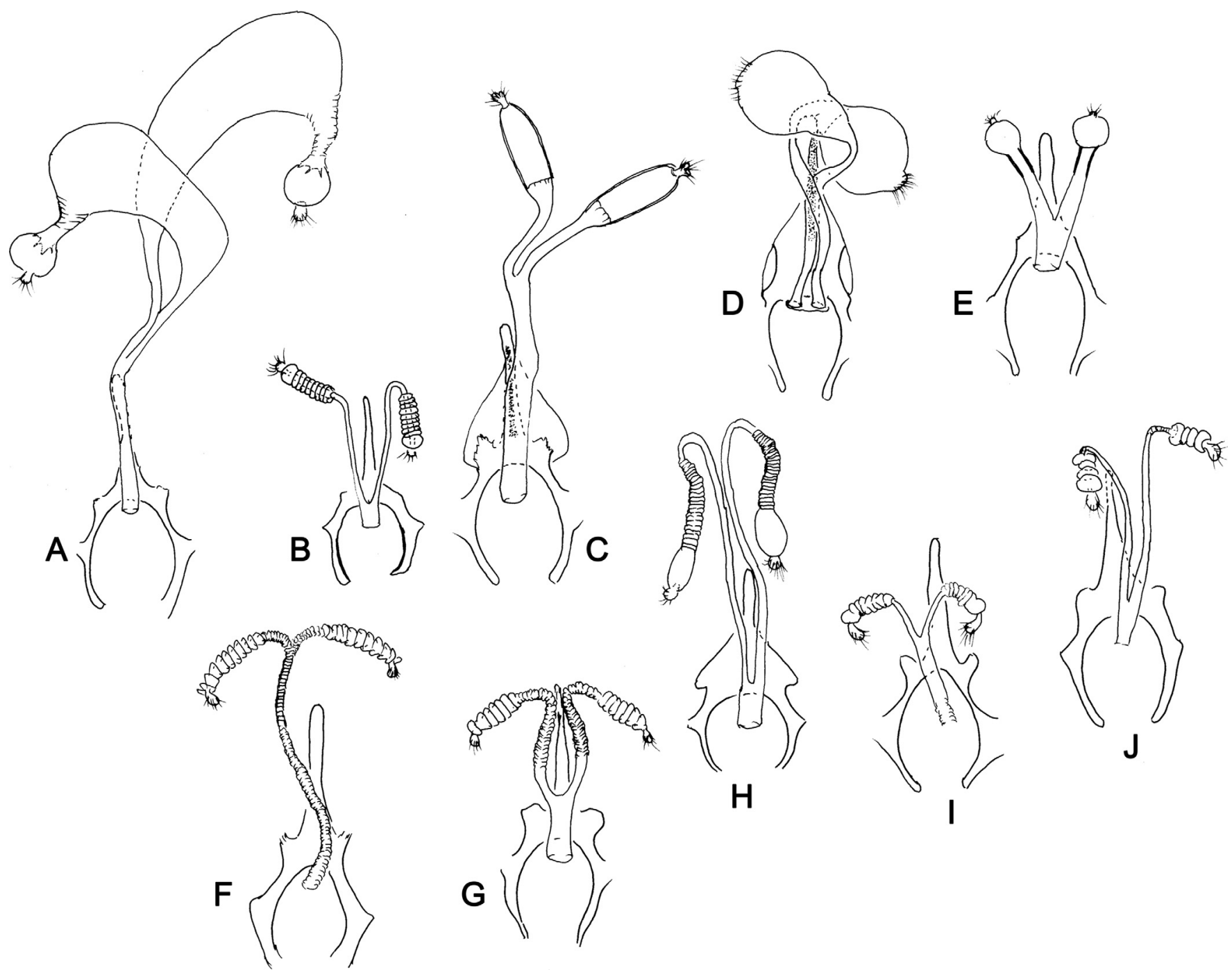

Figure 19. Spermathecae and genital fork aspects of Phlebotominae. (A) Evandromyia (Barrettomyia) tupynambai; (B) Psathyromyia (Psathyromyia) lanei; (C) Pa. (Psa.) shannoni; (D) Pa. (Forattiniella) aragaoi; (E) Pa. (For.) lutziana; (F) Psychodopygus panamensis; (G) Ps. chagasi; (H) Trichophoromyia auraensis; (I) Bichromomyia flaviscutellata; (J) Martinsmyia alphabetica.

permits a detailed description of the species and provides elements for species distinction and phylogenetic studies.

Lastly, an update to the previous proposal for abbreviating the names of genera and subgenera $[8]$ is presented in Table 3.

\section{Other taxonomic approaches}

It is becoming more straightforward to distinguish phlebotomine taxa using modern techniques. The use of statistical approaches, such as models based on discriminant or multivariate analyses used in morphometric studies, may also contribute to the identification of intra- and inter-specific differences.

Concerning the identification of species using methods other than traditional dichotomous keys, the development of cybertaxonomy may facilitate this task for non-specialists or when many specimens need to be identified. The limited number of characters used by this tool may restrict its application in the case of a diverse fauna on a large scale.

One of the significant challenges facing phlebotomine taxonomists is the adoption of an integrative taxonomic 

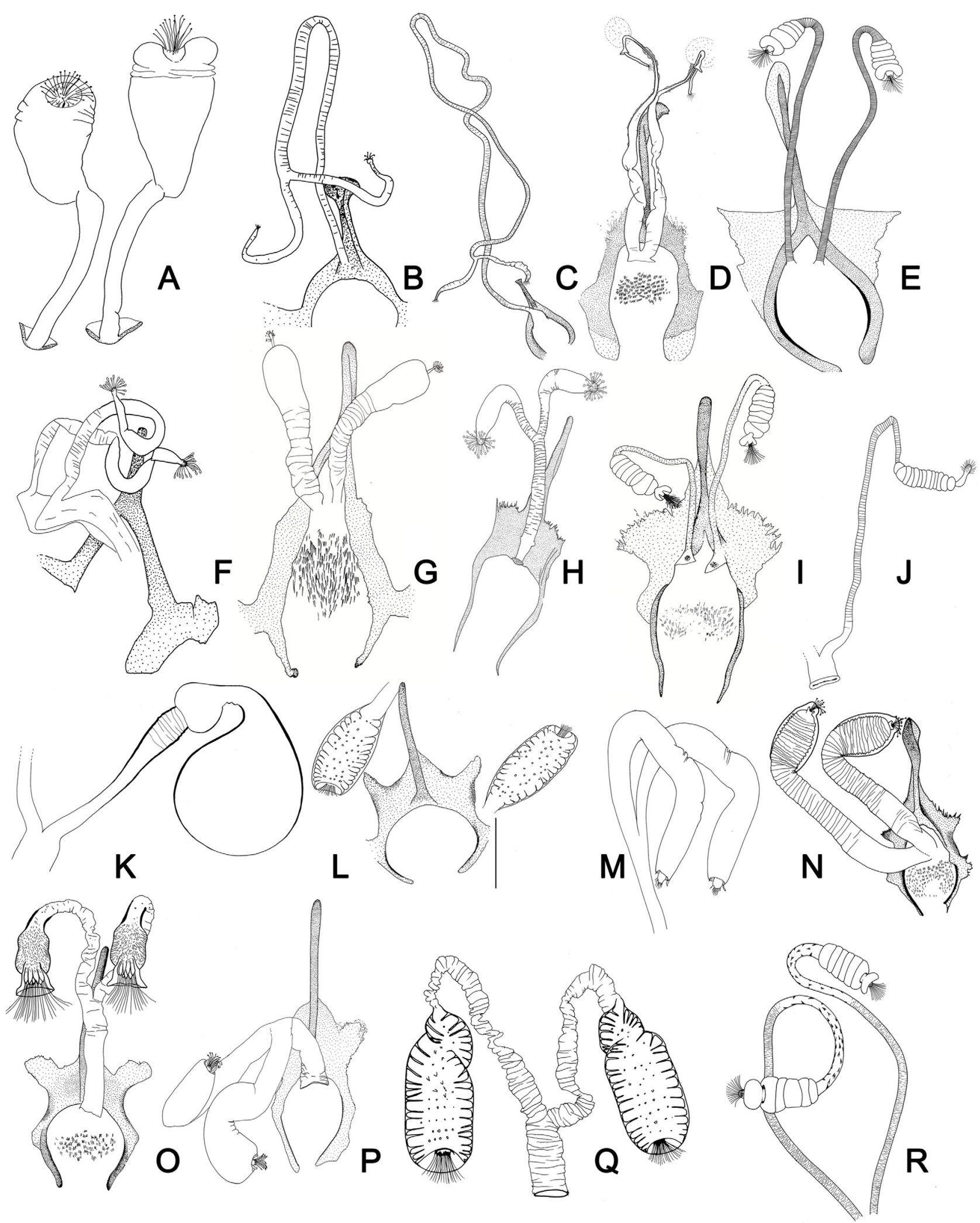

Figure 20. Spermathecae and genital fork aspects of Phlebotominae. (A) Australophlebotomus notteghemae; (B) Chinius eunicegalatiae; (C) Chinius samarensis; (D) Phlebotomus (Madaphlebotomus) vincenti; (E) Ph. (Paraphlebotomus) sergenti; (F) Idiophlebotomus padillarum; (G) Parvidens heishi; (H) Ph. (Euphlebotomus) barguesae; (I) Ph. (Par.) chabaudi; (J) Phlebotomus (Larroussius) major; (K) Spelaeomyia moucheti; (L) Sergentomyia (Rondanomyia) goodmani comorensis; (M) Se. hivernus; (N) Ph. (Transphlebotomus) economidesi; (O) Se. (Vattieromyia) namo; (P) Se. (Sergentomyia) phadangensis; (Q) Sergentomyia (Ron.) goodmani; (R) Ph. (Par.) mireillae. 

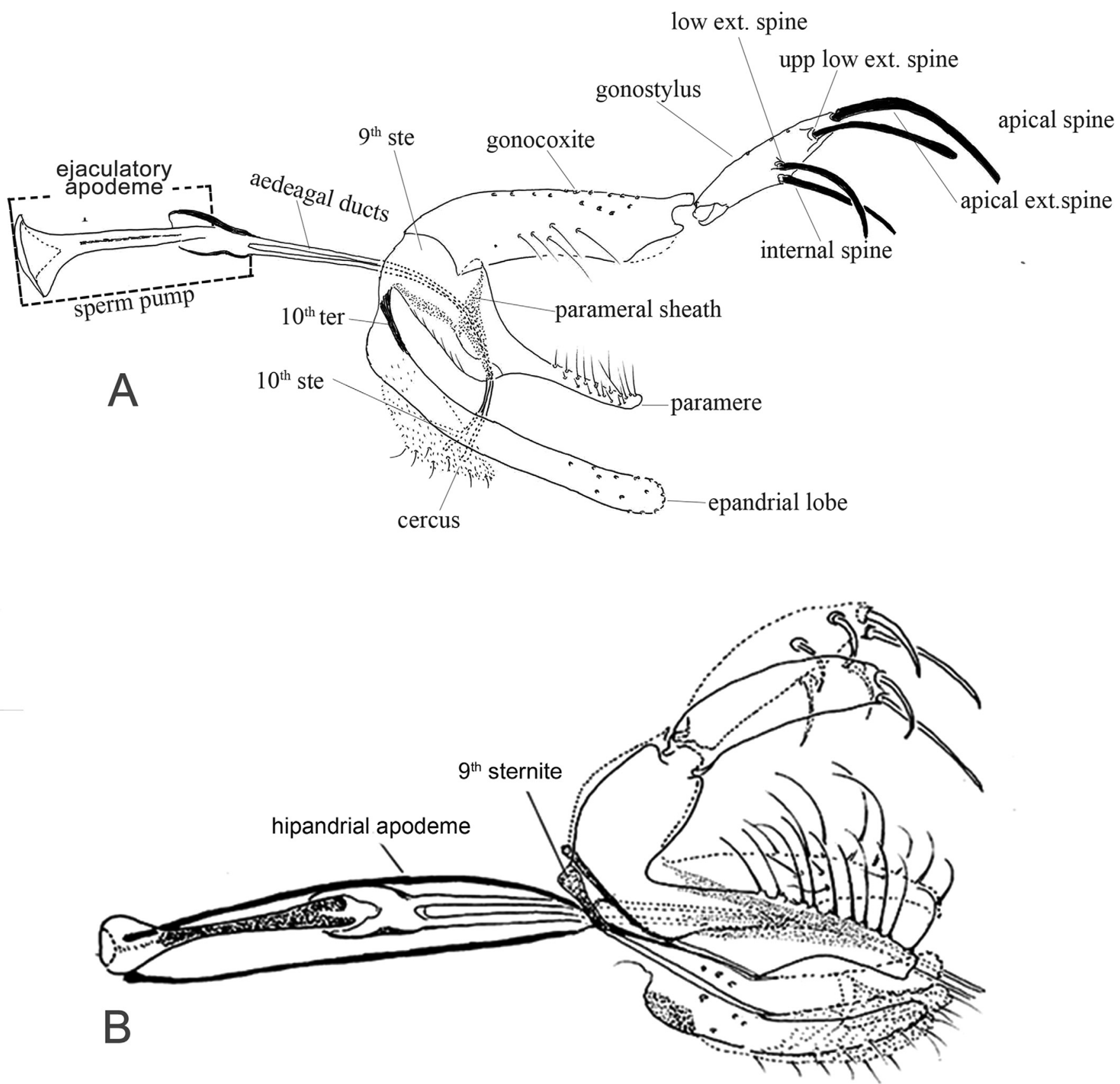

Figure 21. Lateral view of male genitalia of Phlebotominae. (A) Nyssomyia neivai; (B) Warileya nigrosaccula.

approach, with an increase in attention to identifying characters to be used for accurate and efficient delimitation of species. Well-known, common adult morphological and morphometric characters are important; however, others such as behavioral, biochemical, ecological, and molecular data need to be considered, as well as morphological or develop- mental characters related to eggs, larvae, and pupae. It is highly recommended that markers used in molecular analysis for the delimitation of taxa be standardized and gene sequences should be deposited in free-access databases to permit the analysis of species or populations, especially for widespread taxa. This information is also valuable for phylogenetic studies. 


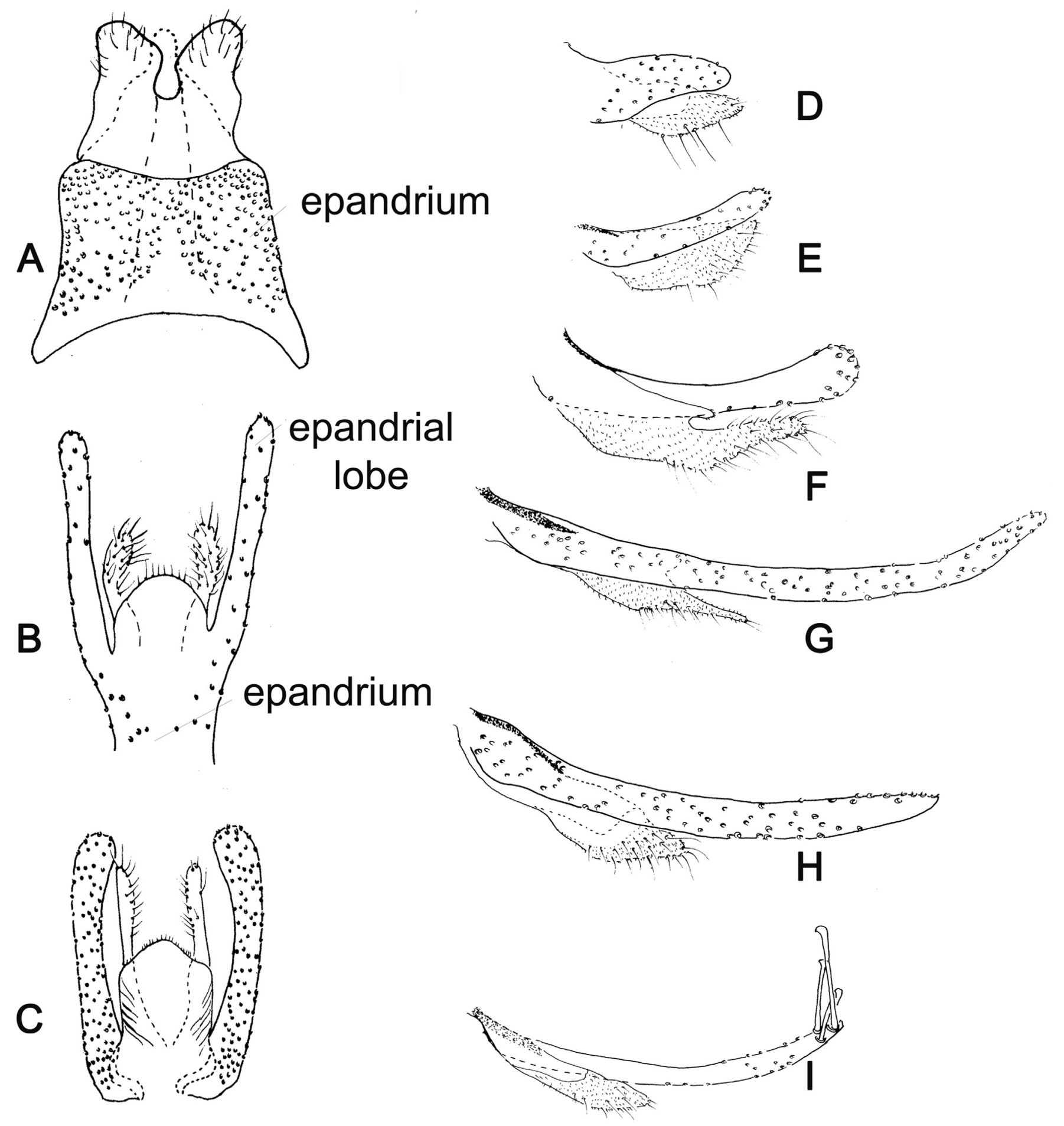

Figure 22. (A-C) Ventral view of the epandrium and of epandrial lobes and cerci of Phlebotominae. (A) Bruchomyiinae (Bruchomyia sp); (B, C) Phlebotominae: (B) Warileya nigrosaccula; (C) Psychodopygus chagasi. (D-I) Lateral view of epandrial lobe and cercus of Phlebotominae: (D) Hertigia hertigi; (E) Sciopemyia sordellii; (F) Psychodopygus chagasi; (G) Trichopygomyia longispina; (H) Evandromyia (Aldamyia) walkeri; (I) Evandromyia (Evandromyia) infraspinosa. 


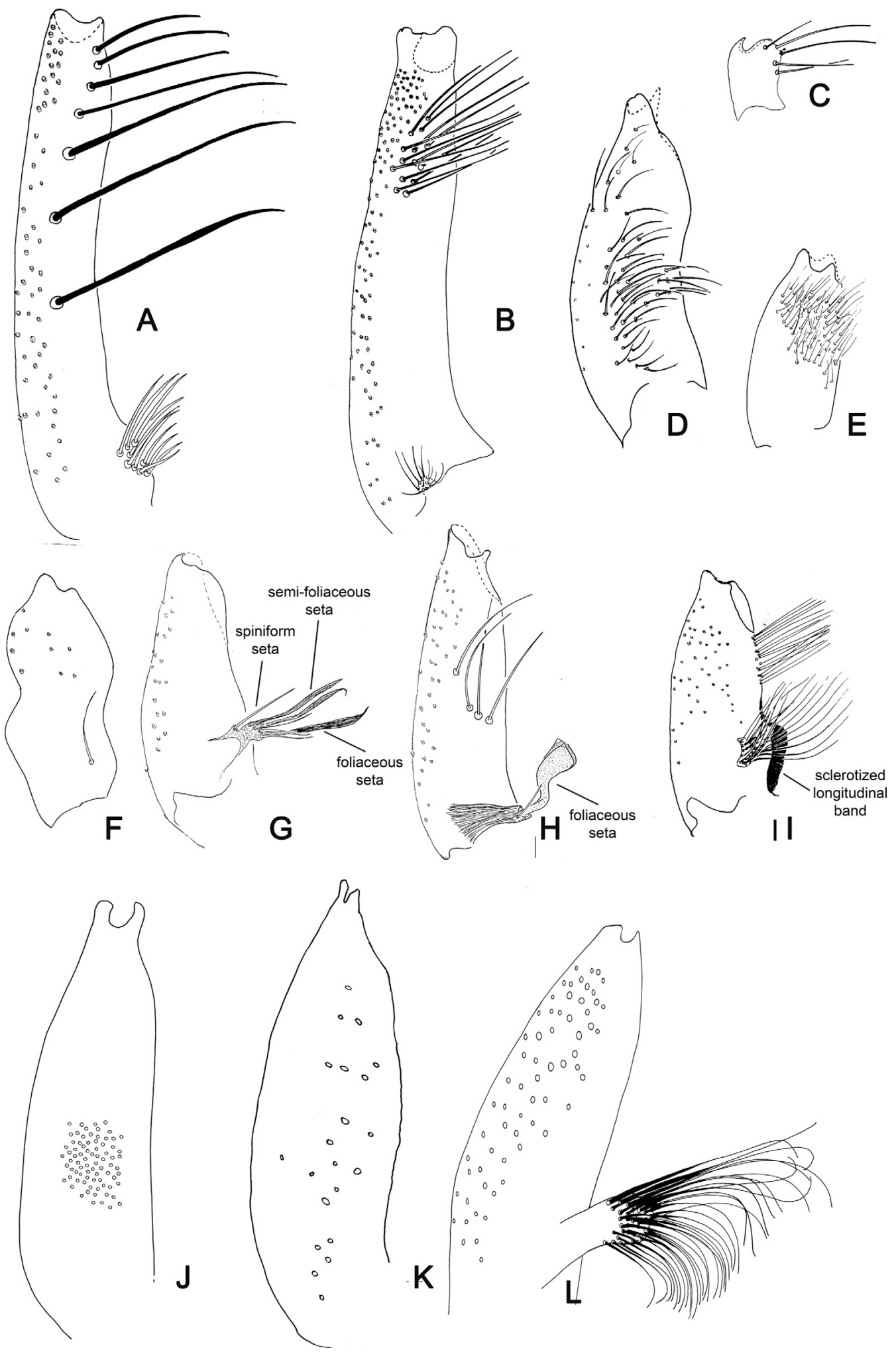

Figure 23. (A-C) Lateral view of gonocoxites of Phlebotominae. (A) Brumptomyia brumpti; (B) Phlebotomus papatasi; (C) Migonemyia (Blancasmyia) gorbitzi; (D) Trichophoromyia auraensis; (E) Micropygomyia (Micropygomyia) pilosa; (F) Psychodopygus chagasi; (G) Lutzomyia (Tricholateralis) carvalhoi; (H) Lutzomyia (Lutzomyia) almerioi; (I) Pintomyia (Pifanomyia) verrucarum; (J) Phlebotomus hindustanicus; (K) Sergentomyia dentata; (L) Phlebotomus mireillae. 


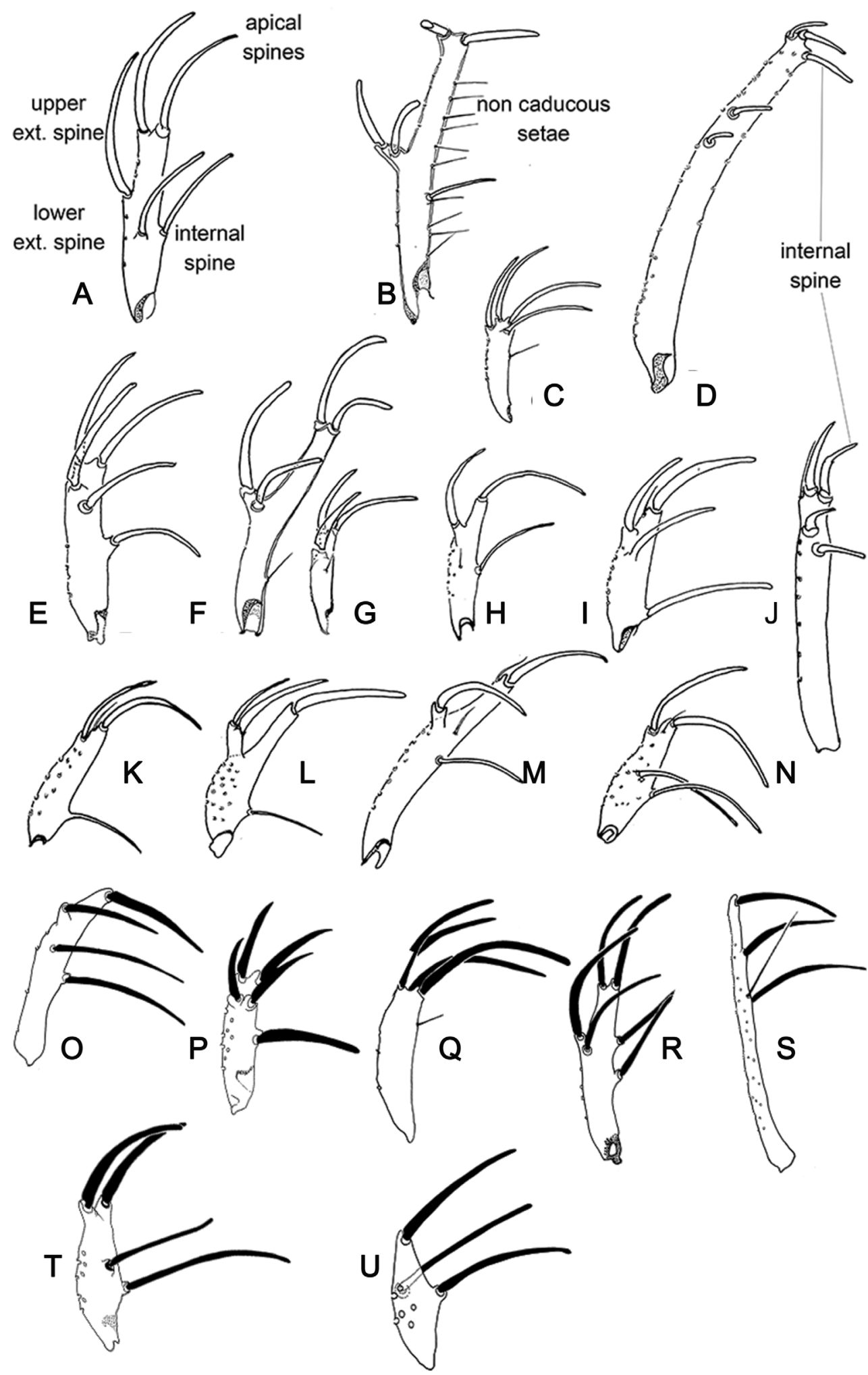

Figure 24. Lateral view of gonostyles of Phlebotominae. (A) Micropygomyia chiapanensis; (B) Brumptomyia cardosoi; (C) Sergentomyia minuta; (D) Phlebotomus papatasi; (E) Edentomyia piauiensis; (F) Oligodontomyia toroensis; (G) Deanemyia samueli; (H) Micropygomyia pilosa; (I) Pintomyia (Pifanomyia) sauroida; (J) Migonemyia (Blancasmyia) gorbitzi; (K) Pintomyia (Pifanomyia) serrana; (L) Evandromyia (Evandromyia) correalimai; (M) Pressatia triacantha; (N) - Evandromyia saulensis; (O) Chinius samarensis; (P) Parvidens heishi; (Q) Sergentomyia - Sergentomyia (Sergentomyia) dentate; (R) Phlebotomus (Transphlebotomus) economidesi; (S) Idiophlebotomus padillarum; (T) Phlebotomus (Paraphlebotomus) andrejevi; (U) Phlebotomus (Legeromyia) multihamatus. 

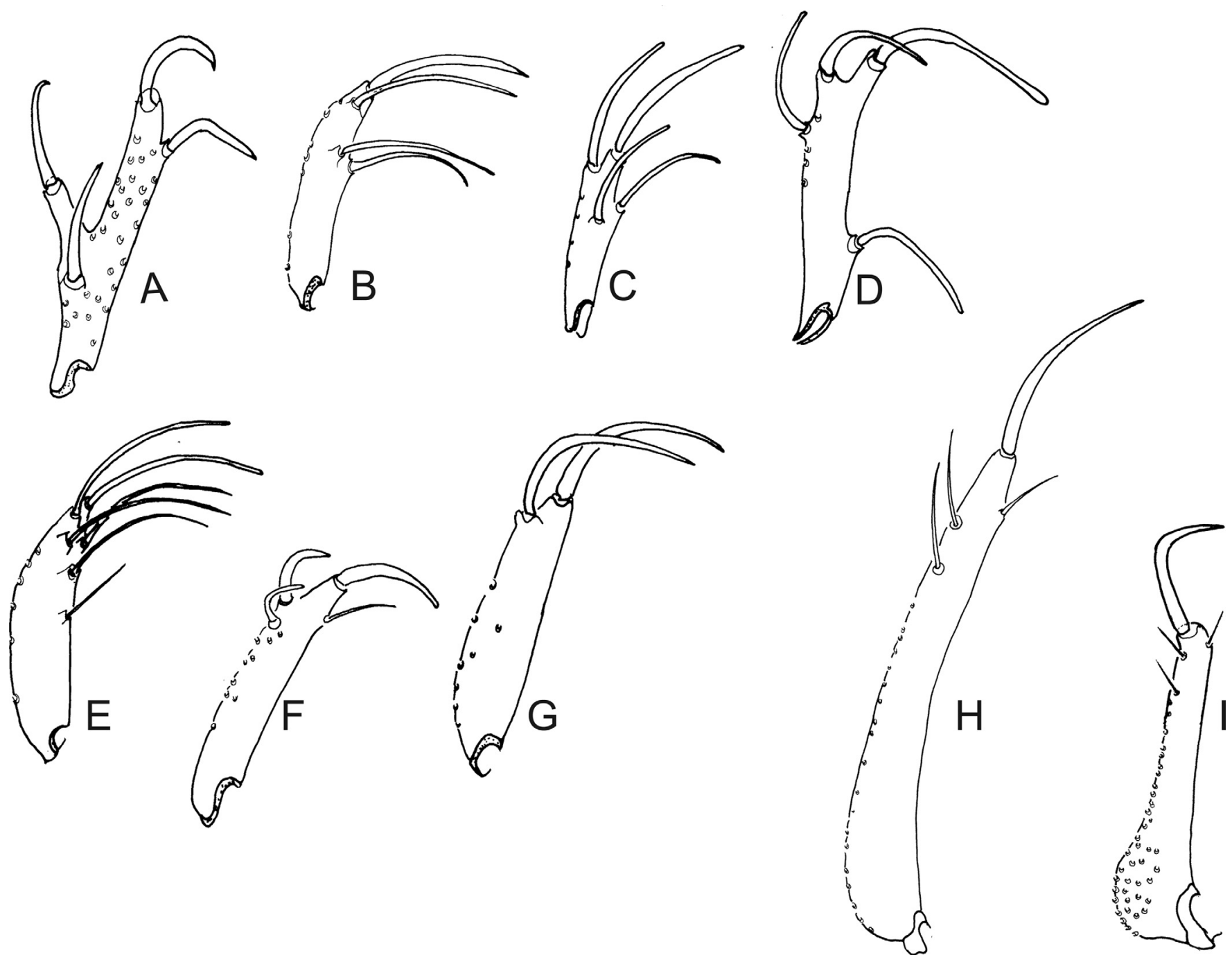

Figure 25. Lateral view of gonostyles of Phlebotominae. (A) Viannamyia tuberculata; (B) Psathyromyia lanei; (C) Bichromomyia flaviscutellata; (D) Trichophoromyia auraensis; (E) Martinsmyia alphabetica; (F) Psychodopygus panamensis; (G) Psychodopygus bispinosus; (H) Psychodopygus geniculatus; (I) Psychodopygus chagasi.

The taxonomy of American phlebotomines has recently been updated regarding the number of described species/subspecies (502: 17 fossil and 485 extant). Additionally, it was commented that there has been an increase of $16.5 \%$ in the number of species described since Galati's classification [3] and of $22.5 \%$ since that of Young and Duncan [11], though, in this latter case, only for the groups that these authors included in Lutzomyia. It was also commented that some taxa had been resurrected, some other species had been included as junior synonyms and two artificial taxa had been excluded from the species list. It is important to note that Galati's classification has been updated annually and is available on the website: www.fsp.usp.br/ egalati [5].

Finally, the need to strengthen the training of taxonomist groups around the world was emphasized in view of the fact that taxonomy is the basis of the eco-epidemiological studies of vector-borne diseases. In recent years, with the advances of new technologies, particularly the molecular approach, a low level of interest on the part of young researchers in classical taxonomy has been observed that could lead to a significant loss of knowledge because expertise in this field depends on the strength of training and mentorship over successive generations. 


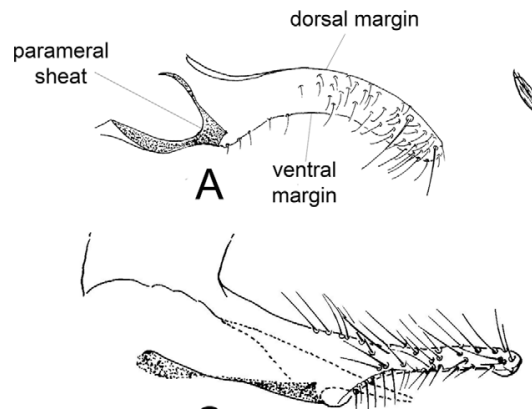

C
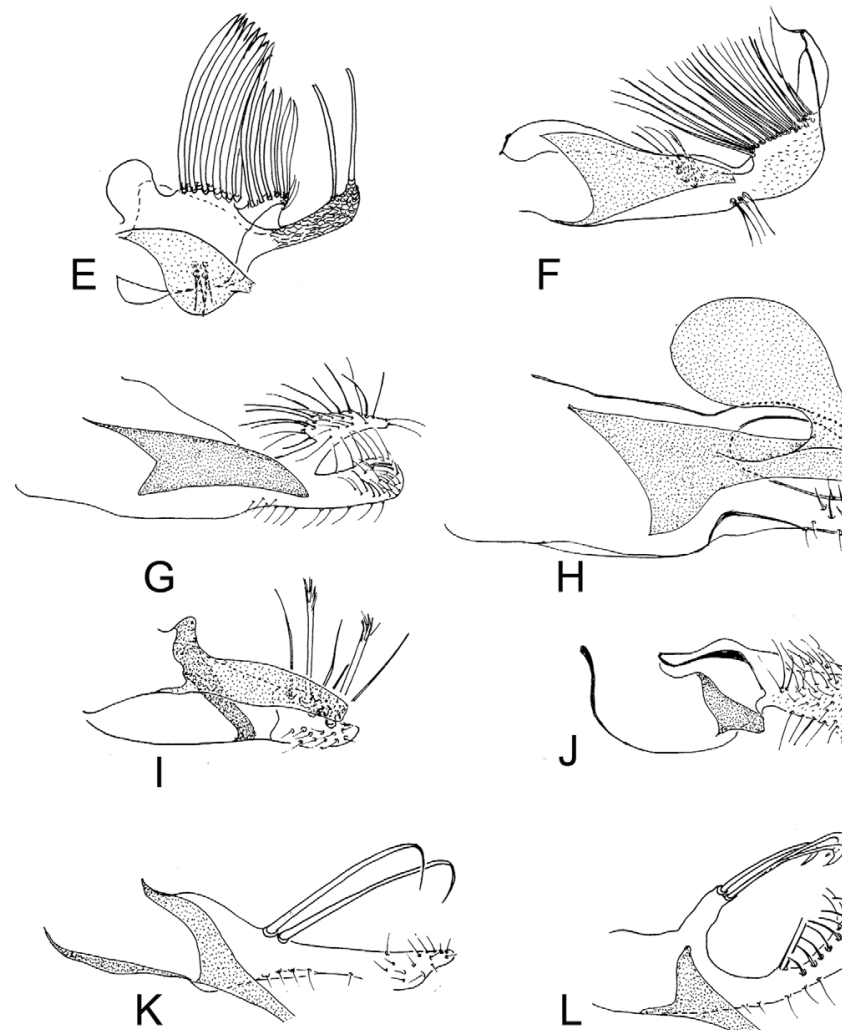

$\mathrm{F}$
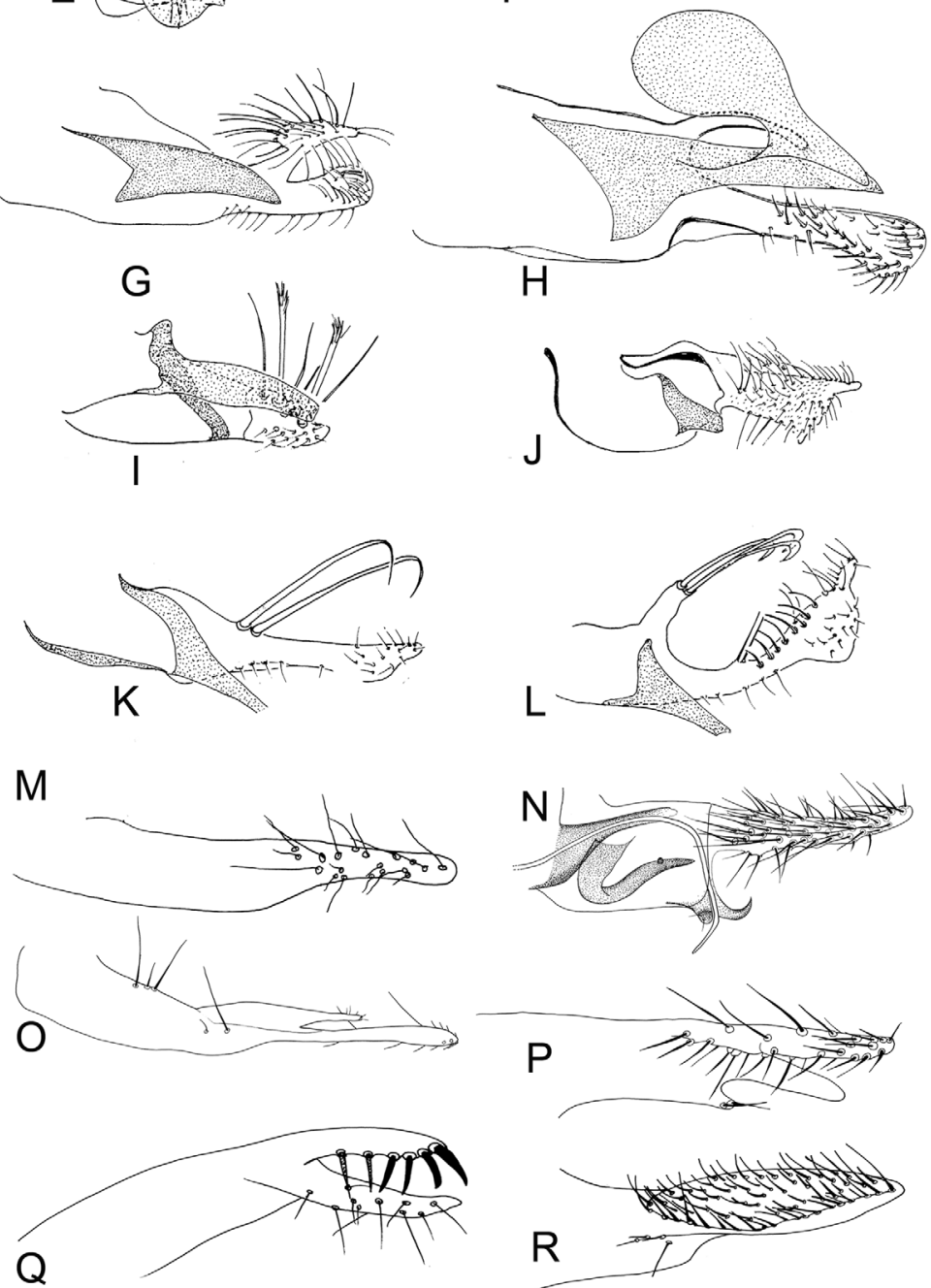

Figure 26. Lateral view of paramere and parameral sheath of Phlebotominae. (A) Migonemyia (Blancasmyia) gorbitzi; (B) Evandromyia (Aldamyia) walkeri; (C) Lutzomyia (Helcocyrtomyia) guderiani; (D) Psathyromyia (Psathyromyia) lanei; (E) Psychodopygus panamensis; (F) Psychodopygus chagasi; (G) Trichopygomyia longispina; (H) Trichopygomyia dasypodogeton; (I) Viannamyia tuberculata; (J) Pressatia triacantha;(K) Lutzomyia (Lutzomyia) longipalpis; (L) Lutzomyia (Lutzomyia) dispar; (M) Sergentomyia (Sergentomyia) dentate; (N) Phlebotomus (Legeromyia) multihamatus; (O) Idiophlebotomus padillarum; (P) Phlebotomus (Euphlebotomus) barguesae; (Q) Parvidens heishi; (R) Phlebotomus (Paraphlebotomus) andrejevi. 

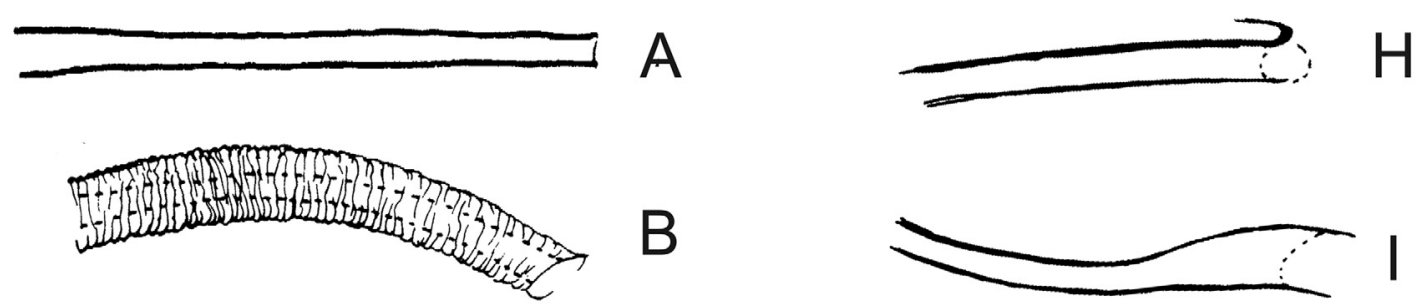

H
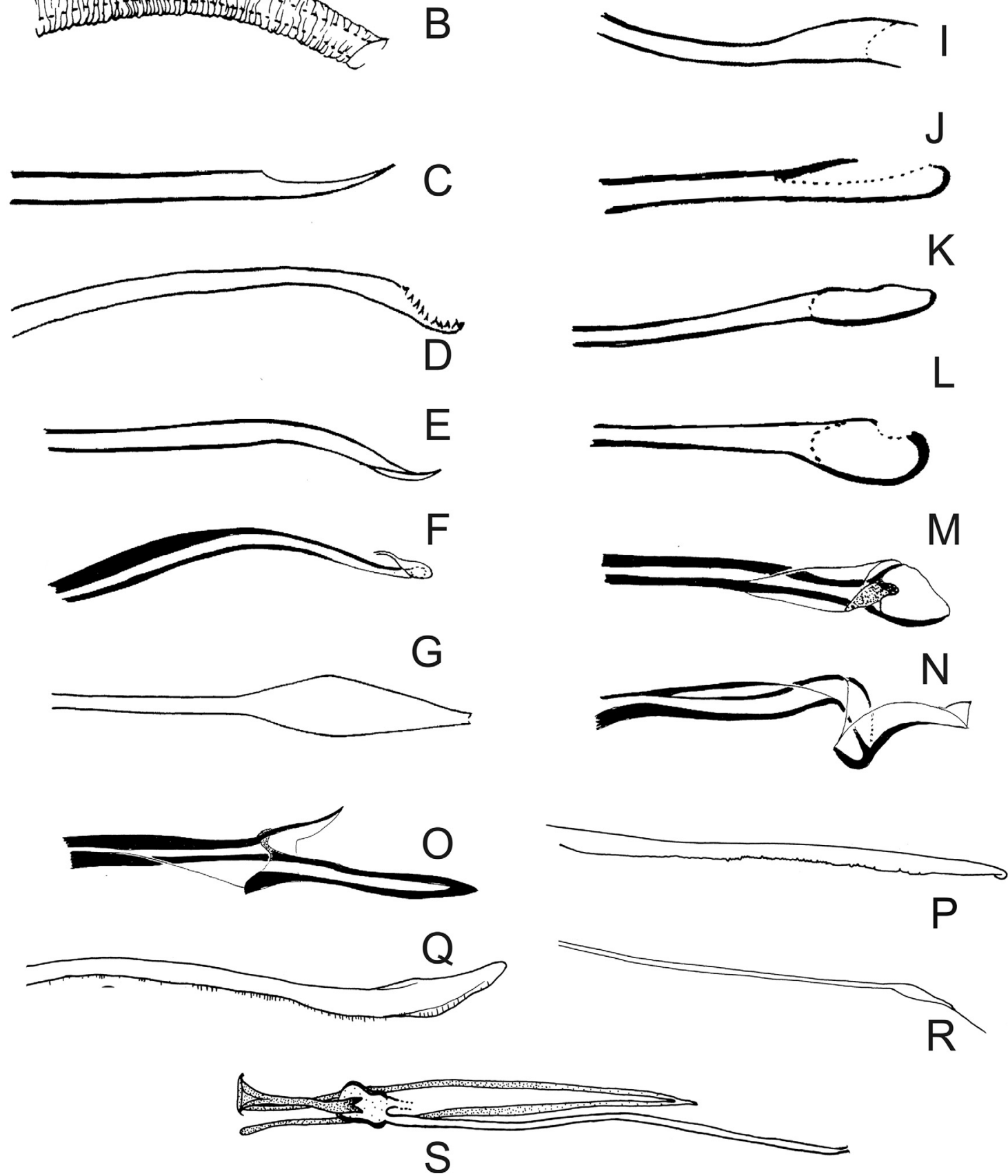

Figure 27. (A-R) Lateral view of terminal region of aedeagal ducts of Phlebotominae. (S) Genital pump, aedeagal ducts and hypandrial apodemes (abdominal rods). (A) Blunt apex: Lu. longipalpis; (B) striated duct with blunt apex: Ev. brachyphalla; (C) apex beveled: Pa. shannoni; (D) curved and toothed apex: Ma. gasparviannai; (E) curved and beveled apex: Mi. longipennis; (F) duct curved in its preapical region and apex provided with appendix: Vi. tuberculata; (G) lozenge apex: Pa. runoides; $(\mathrm{H})$ apex with barbs: Ny. yuilli pajoti; (I-J) bifurcated apex: (I) Ny. whitmani; (J) Nyssomyia anduzei, (K) ladle-shaped apex: Ny. intermedia, (L) spoon shaped or knife to eat fish shaped: Ny. neivai; (M) clavate apex: Ev. walkeri; (N) duct with curved preapical region and blunt apex: Pa. aragaoi; (O) strongly sclerotized bifurcated apex: Ev. lenti; (P) irregular side: Se. anka; (Q) enlarged at the top: Se. sclerosiphon; (R) with apical inflated portion: Id. padillarum. (S) Terminal region of aedeagal ducts with blunt apex: Id. nicolegerae. 

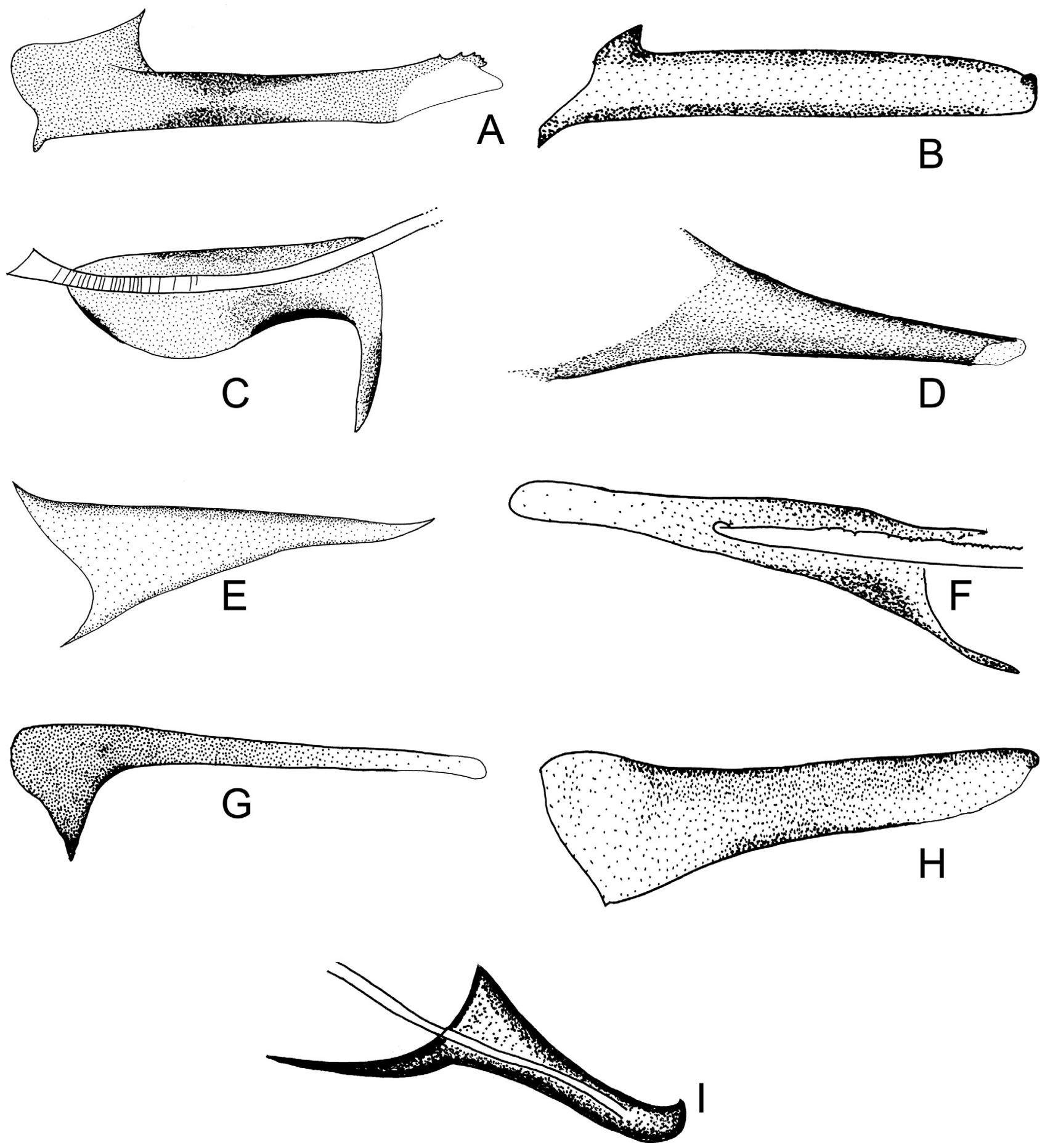

Figure 28. Parameral sheath of Phlebotominae. (A) With a transparent inferior top: Phlebotomus perfiliewi; (B) rounded with a knob at the top: Idiophlebotomus nicolegerae; (C) wide and short: Chinius eunicegalatiae; (D) with transparent top: Phlebotomus (Euphlebotomus) barguesae; (E) pointed: Phlebotomus (Paraphlebotomus) chabaudi; (F) rounded at the top: Sergentomyia (Vattieromyia) anka; (G) drumsticklike: Phlebotomus (Larroussius) major; (H) finger-like: Phlebotomus (Madaphlebotomus) vaomalalae; (I) with hooked top: Phlebotomus (Paraphlebotomus) mongolensis. 
Table 3. Proposed abbreviations for genera and subgenera of Phlebotominae.

\begin{tabular}{|c|c|c|c|}
\hline Genus & Abbreviation & Subgenus & Abbreviation \\
\hline Australophlebotomus Theodor & $A u$. & & \\
\hline Brumptomyia França \& Parrot & $B r$ & & \\
\hline \multicolumn{4}{|l|}{ Chinius Leng } \\
\hline \multirow[t]{3}{*}{ Dampfomyia Addis } & $D a$. & & \\
\hline & & Coromyia Barretto & Cor: \\
\hline & & Dampfomyia & Dam. \\
\hline Deanemyia Galati & De. & & \\
\hline $\begin{array}{l}\text { Edentomyia Galati, Andrade Filho, Silva \& } \\
\text { Falcão }\end{array}$ & $E d$. & & \\
\hline \multirow[t]{4}{*}{ Evandromyia Mangabeira } & $E v$. & & \\
\hline & & Aldamyia Galati & Ald. \\
\hline & & Barrettomyia Martins \& Silva & Bar. \\
\hline & & Evandromyia & Eva. \\
\hline Expapillata Galati & Ex. & & \\
\hline Grassomyia Theodor & $G r$ & & \\
\hline Hertigia Fairchild & $\mathrm{He}$. & & \\
\hline Idiophlebotomus Quate \& Fairchild & $I d$. & & \\
\hline${ }^{\dagger}$ Libanophlebotomus Azar & $L b$. & & \\
\hline \multirow[t]{5}{*}{ Lutzomyia França } & $L u$. & & \\
\hline & & Castromyia Mangabeira & Cas. \\
\hline & & Lutzomyia & Lut. \\
\hline & & Helcocyrtomyia Barretto & Hel. \\
\hline & & Tricholateralis Galati & $\operatorname{Trl}$ \\
\hline Martinsmyia Galati & Mt. & & \\
\hline${ }^{\dagger}$ Mesophlebotomites Azar & $M e$. & & \\
\hline \multirow[t]{5}{*}{ Micropygomyia Barretto } & Mi. & & \\
\hline & & Coquillettimyia Galati & Col. \\
\hline & & Micropygomyia & Mic. \\
\hline & & Sauromyia Artemiev & Sau. \\
\hline & & Silvamyia Galati & Sil. \\
\hline \multirow[t]{3}{*}{ Migonemyia Galati } & $M g$. & & \\
\hline & & Blancasmyia Galati & Bla. \\
\hline & & Migomemyia & Mig. \\
\hline Nyssomyia Barretto & $N y$. & & \\
\hline Oligodontomyia Galati & Ol. & & \\
\hline${ }^{\dagger}$ Palaeomyia Poinar Jr, & $P l$. & & \\
\hline Parvidens Theodor \& Mesghali & $P v$ & & \\
\hline${ }^{\dagger}$ Phlebotoiella Solórzano Kraemer \& Wagner & $P b$. & & \\
\hline${ }^{\dagger}$ Phlebotomiella Hennig & $P e$. & & \\
\hline${ }^{\dagger}$ Phlebotomites Meunier & $P t$. & & \\
\hline \multirow[t]{13}{*}{ Phlebotomus Rondani \& Berté } & Ph. & & \\
\hline & & $\begin{array}{l}\text { Abonnencius Morillas Marquez, Castillo Remiro \& Ubeda } \\
\text { Ontiveros }\end{array}$ & Abo. \\
\hline & & Adlerius Nitzulescu & Adl. \\
\hline & & Anaphlebotomus Theodor 1948 & Ana. \\
\hline & & Euphlebotomus Theodor, 1948 & Eup. \\
\hline & & Kasaulius Lewis & Kas. \\
\hline & & Larroussius Nitzulescu & Lar. \\
\hline & & Legeromyia Rahola, Depaquit, Makanga \& Paupy & Leg. \\
\hline & & Madaphlebotomus Depaquit, Leger, Randrianambinintsoa & Mad. \\
\hline & & Paraphlebotomus Theodor & Par. \\
\hline & & Phlebotomus & Phl. \\
\hline & & Synphlebotomus Theodor & Syn. \\
\hline & & Transphlebotomus Artemiev & Tra. \\
\hline \multirow[t]{3}{*}{ Pintomyia Costa Lima } & $P i$. & & \\
\hline & & Pifanomyia Ortiz \& Scorza & Pif. \\
\hline & & Pintomyia & Pin. \\
\hline Pressatia Mangabeira & $\operatorname{Pr}$. & & \\
\hline \multirow[t]{2}{*}{ Psathyromyia } & $P a$. & & \\
\hline & & Forattiniella Vargas & For. \\
\hline
\end{tabular}


Table 3. (continued)

\begin{tabular}{|c|c|c|c|}
\hline Genus & Abbreviation & Subgenus & Abbreviation \\
\hline & & Psathyromyia & Psa. \\
\hline & & Xiphopsathyromyia Ibánez-Bernal \& Marina & Xip. \\
\hline Psychodopygus Mangabeira & PS. & & \\
\hline Sciopemyia Barretto & Sc. & & \\
\hline \multirow[t]{11}{*}{ Sergentomyia França \& Parrot } & Se. & & \\
\hline & & Capensomyia Davidson, 1979 & Cap. \\
\hline & & Demeillonius Davidson & Dem. \\
\hline & & Grassomyia* & Gra. \\
\hline & & Neophlebotomus França \& Parrot & Neo. \\
\hline & & Parrotomyia Theodor & Par. \\
\hline & & Rondanomyia Theodor & Ron. \\
\hline & & Sergentomyia & Ser. \\
\hline & & Sintonius Nitzulescu & Sin. \\
\hline & & Trouilletomyia Depaquit, Léger \& Randrianambinintsoa & Tro. \\
\hline & & Vattieromyia Depaquit, Léger \& Robert & Vat. \\
\hline Spelaeomyia Theodor & Sa. & & \\
\hline Spelaeophlebotomus Theodor & Sl. & & \\
\hline Trichophoromyia Barretto & $T h$. & & \\
\hline Trichopygomyia Barretto & Ty. & & \\
\hline Viannamyia Mangabeira & Vi. & & \\
\hline Warileya Hertig & $W a$. & & \\
\hline
\end{tabular}

* If considered as a subgenus;

$\dagger$ Fossil.

Acknowledgements. The authors are grateful to the two reviewers, José Dilermando Andrade Filho and Gregory Curler, for their work on this manuscript.

\section{References}

1. Croset H, Abonnenc E, Rioux J. 1970. Phlebotomus (Paraphlebotomus) chabaudi n. sp. (Diptera-Psychodidae). Annales de Parasitologie Humaine et Comparée, 45, 863-873.

2. Cumming JM, Wood DM. 2009. Adult morphology and terminology, in Manual of Central American Diptera, vol. 1, Brown BV, Borkent A, Cumming JM, Wood DM, Woodley NE, Zumbado MA, Editors. National Research Council of Ottawa: Canada. p. 9-502.

3. Galati EAB. 2003. Classificação de Phlebotominae, in Flebotomíneos do Brasil. Rangel EF, Lainson R, Editors. Ed. Fiocruz: Rio de Janeiro. p. 23-51.

4. Galati EAB. 2016. Phlebotominae (Diptera, Psychodidae): Classificação, morfologia, terminologia e identificação de Adultos, Apostila - Disciplina PSP5127-1 Bioecologia e Identificação de Phlebotominae. Public Heath School. University of São Paulo, www.fsp.usp.br/ egalati.

5. Depaquit J, Pesson B, Augot D, Hamilton JG, Lawyer P, Léger N. 2016. Proceedings of the IX International Symposium on Phlebotomine Sandflies (ISOPS IX), Reims, France, June 28th-July 1st, 2016. Parasite, 23, E1.
6. International Commission on Zoological Nomenclature. 1999. International Code of Zoological Nomenclature, 4th edn., London, UK: The International Trust for Zoological Nomenclature.

7. McAlpine JF. 1981. Morphology and terminology - adults, in Manual of Nearctic Diptera, vol. 1, McAlpine JF, Peterson BV, Shewell GE, Teskey HJ, Vockeroth JR, Wood DM, Editors. Research Branch Agriculture: Canada, Monograph No. 27, Newstead R 1912. Notes, 9-23.

8. Marcondes CB. 2007. A proposal of generic and subgeneric abbreviations for Phlebotomine sandflies (Diptera: Psychodidae: Phlebotominae) of the World. Entomological News, 118, 351-356.

9. Rahola N, Depaquit J, Makanga BK, Paupy C. 2013. Phlebotomus (Legeromyia) multihamatus subg. nov., sp. nov. from Gabon (Diptera: Psychodidae). Memórias do Instituto Oswaldo Cruz, 108(7), 845-849.

10. Ubeda Ontiveros JM, Morillas Marquez F. 1983. Designacion del holotipo de Phlebotomus fortunatarum Ubeda Ontiveros y col., 1982 (Diptera, Phlebotomidae). Revista Iberica de Parasitologia, 43, 307-308.

11. Young DG, Duncan MA. 1994. Guide to the identification and geographic distribution of Lutzomyia sand flies in Mexico, the West Indies, Central and South America (Diptera: Psychodidae). Memoirs of the American Entomology Institute, $54,1-881$. 
Cite this article as: Galati EAB, Galvis-Ovallos F, Lawyer P, Léger N \& Depaquit J: An illustrated guide for characters and terminology used in descriptions of Phlebotominae (Diptera, Psychodidae). Parasite, 2017, 24, 26.

\section{(0) PARASTE}

An international open-access, peer-reviewed, online journal publishing high quality papers on all aspects of human and animal parasitology

Reviews, articles and short notes may be submitted. Fields include, but are not limited to: general, medical and veterinary parasitology; morphology, including ultrastructure; parasite systematics, including entomology, acarology, helminthology and protistology, and molecular analyses; molecular biology and biochemistry; immunology of parasitic diseases; host-parasite relationships; ecology and life history of parasites; epidemiology; therapeutics; new diagnostic tools.

All papers in Parasite are published in English. Manuscripts should have a broad interest and must not have been published or submitted elsewhere. No limit is imposed on the length of manuscripts.

Parasite (open-access) continues Parasite (print and online editions, 1994-2012) and Annales de Parasitologie Humaine et Comparée (1923-1993) and is the official journal of the Société Française de Parasitologie. 